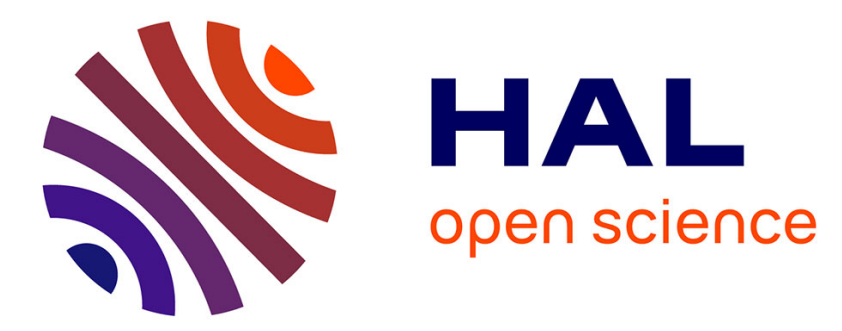

\title{
Mineralogical and microtextural parameters in metals ores traceability studies
}

Julie Machault, Luc Barbanson, Thierry Augé, Laurent Bailly, Jean-Jacques

Orgeval

\section{- To cite this version:}

Julie Machault, Luc Barbanson, Thierry Augé, Laurent Bailly, Jean-Jacques Orgeval. Mineralogical and microtextural parameters in metals ores traceability studies. Ore Geology Reviews, 2014, 63, pp.307-327. 10.1016/j.oregeorev.2014.05.019 . insu-01003502

\section{HAL Id: insu-01003502 \\ https://hal-insu.archives-ouvertes.fr/insu-01003502}

Submitted on 24 Jun 2014

HAL is a multi-disciplinary open access archive for the deposit and dissemination of scientific research documents, whether they are published or not. The documents may come from teaching and research institutions in France or abroad, or from public or private research centers.
L'archive ouverte pluridisciplinaire HAL, est destinée au dépôt et à la diffusion de documents scientifiques de niveau recherche, publiés ou non, émanant des établissements d'enseignement et de recherche français ou étrangers, des laboratoires publics ou privés. 


\title{
Mineralogical and microtextural parameters in metals ores traceability studies
}

Julie Machault (1, 2, 3,*), Luc Barbanson (1), Thierry Augé (2), Laurent Bailly (2) and JeanJacques Orgeval (4)

(1) Institut des Sciences de la Terre d'Orléans (ISTO) - Université d'Orléans/CNRSINSU/BRGM - UMR 7327 - 1A rue de la Férollerie 45071 Orléans Cedex 2, France.

(2) Bureau de Recherches Géologiques et Minières (BRGM) - Direction des Géoressources (DGR/MIN) - 3 avenue Claude Guillemin BP 3600945060 Orléans Cedex 2, France.

(3) Now in Université de Lorraine, CNRS, CREGU, GeoRessources lab. - UMR 7359 - Bât. A, 2 rue du doyen Marcel Roubault 54518 Vandoeuvre-lès-Nancy, France.

(4) 16 Allée du Houx 45160 Olivet, France.

*Corresponding author: Julie Machault (j.machault@gmail.com)

E-mail address: Julie Machault (j.machault@gmail.com), Luc Barbanson (luc.barbanson@univ-orleans.fr), Thierry Augé (t.auge@brgm.fr), Laurent Bailly (1.bailly@brgm.fr) and Jean-Jacques Orgeval (orgeval@3dnet.fr)

\begin{abstract}
$\underline{\text { Abstract }}$
The demand in mineral resources is increasing rapidly, but there is a lack of transparency in the trade of concentrated raw mineral materials because of speculation and involvement in the finance of armed conflicts. Due to the distance between primary extraction and the final production sites it is difficult to check the origin of these products. An identity card is required for mineral commodities, so that trading in the industry can be verified and the traceability of concentrates ensured. This problem may be considered as an inversion process: studying the products sold to identify the original ore. The discriminant parameters are mineralogical composition, identification of textural microfacies of the target minerals, "pseudo-paragenetic sequence", and the contents and distribution of minor elements of target minerals. For base metal, the selected target minerals are pyrite, for its ubiquity, sphalerite for its ability to host numerous discriminant and potentially valuable minor elements in its lattice and chalcopyrite for its proximity with the two other minerals. The Kolmogorov-Smirnov distance and the Colin-White test are used to compare the chemical composition of the three target minerals. The application to Volcanic Massive Sulfide ore deposits shows that it is possible to distinguish pyrite, sphalerite and chalcopyrite between two ore deposits in the Iberian Pyrite Belt province and seven ore deposits from the Urals province using the selected characteristics. Ore deposits from different provinces may be discriminated using the identity cards, as well as different deposits in the same province.
\end{abstract}

Keywords: traceability, identity card, target minerals, Kolmogorov-Smirnov, Colin-White, Volcanic Massive Sulfide. 


\section{$\underline{1 \text { Introduction }}$}

Metal mining and marketing have an impact on the economy, society (negative: war, infrastructure damage, exploitation of children, poor working conditions or positive: provides a life basis for many people in less-developed countries, accesses deposits which are otherwise uneconomic) and the environment. The metal market is a major factor in economic development. This is a major concern in developed countries, which are anxious to secure supplies in view of the strong demand for mobile phones, digital tablets, solar panels, batteries, ... It is also a growing concern for the "citizen-consumer", who needs to be sure that theses items have not been produced contrary to his ethical or moral values (for example involving child labor, destruction of non-renewable resources, untreated pollution, ...). To avoid parallel markets of certain mineral resources, solutions have been proposed to locate the extraction sites of these resources for diamond via the Kimberley Process (www.kimberleyprocess.com), for emeralds (Giuliani et al., 1998 a and b), sapphire (Giuliani et al., 2005), ruby (Giuliani et al., 2005) and "coltan" (Melcher et al., 2008 a and b, 2013; Gäbler et al., 2011, 2013; Savu-Krohn et al., 2011). A chain of control and certification has been set up by the diamond producer countries under the supervision of international experts. All diamonds must be accompanied by a certificate of origin (Kimberley process). The development of the ${ }^{18} \mathrm{O} /{ }^{16} \mathrm{O}$ isotopic identity card for emeralds helps to distinguish the source of a large number of high quality emeralds (Giuliani et al., 1998 b). Fingerprints of coltan can be determined to find the place of origin of the mineral (Melcher et al., 2008 a and b, 2013; Gäbler et al., 2011, 2013; Savu-Krohn et al., 2011). A similar need sometimes arises during mineral processing when multiple sources are used. The Luossavaara Kiirunavaara AB-plant (LKAB) in Sweden produces iron ore from Kiruna and Malmberget mines. These minerals are mixed. Iron oxides of Malmberget are different from those from Kiruna (coarser-grained, different types of joints of grains, ...) (Oghazi et al., 2009) and behave differently during treatment. To clarify the importance of the source of the ore on the difficulties observed during treatment, a traceabilty study was attempted (Kvarnström and Oghazi, 2008; Machault et al., 2013). However, there are very few studies on the traceability of base metals. These metals are mainly used in industrial sectors such as transport, construction and electronics and the evolution of their price depends to a large extent of the growth of the global economy. Production of base metals is characterized by complex mineral processing of a bulk ore before metallurgical treatment and this complicates the traceability problem.

The aim of this work is to establish parameters to be included in an identity card for each deposit, which will allow it to be discriminated from other deposits. This requires a method of traceability with low analytical cost, using easily accessible techniques. Mineralogical and microtextural characterization allows a unique signature to be established for each ore and each deposit studied. The samples used for this study are only representative of the production $\mathrm{t}$ time given and it is in this sense only that they ae representative. The ultimate objective of this study, which is part of a global programme to create an ore identity card, is the establishment of a database incorporating the characteristics of each deposit and each mineral processing plant (Machault et al., 2013). Periodic reviews of the database will ensure monitoring of traceability parameters over time. 


\section{An approach for the traceability of base metals in Volcanogenic Massive Suphide}

Traceability refers to the ability to track a product at different stages of its production, its transformation and its commercialization from the source of the product up to the end of its life, including possible recycling. It must allow the origin of the source concentrate to be determinated at each of these stages. Procedures to achieve a good traceability are governed by standards and / or national or international control organizations (for example, the international standards organization (ISO)). In the case of mineral ressources, traceability consists in associating a commodity to the mine from which it has been extracted. Previous studies on precious stones (Kimberley process; Giuliani et al., 1998 a and b, 2005) or metals (Oghazi et al., 2009; Kvarnström and Oghazi, 2008) have shown that the mineralogy of the bulk ore can commonly give clues to a successful traceability method. For base metals, the bulk ores bear mineralogical differences, which may provide characteristics to track the bulk ore. These characteristics may "survive" during mineral processing, so that we can find "footprints" of bulk ore in the concentrate. Hence metal ore traceability implies that, in the ideal case, for each province and also for each deposit, valuable minerals have an unique signature. The characteristics that can be observed in concentrate at grain-scale (mineralogical composition, chemical composition of the phases, microtexture) will depend on 1) the process of formation of the mineralization and its post-deposit history and 2) the local geological setting including the host rocks. The first factor refers to the type of ore deposit (massive sulphides, skarn, porphyry copper,...), while the second factor corresponds to the regional setting which is sometimes poorly understood. The assignment to a type is a first step toward the determination of the concentrate origin; regional factors could further help to refine the approach. The concentrate is not only derived from natural processes, but also industrial processes (i.e. milling, grinding, flotation), which must be taken into account. In addition to the processing difficulties like mixing of bulk ores (Kvarnström and Oghazi, 2008) we can not exclude variations over time in the operation of a given mineralurgical plant. Finally, within a given mine, the nature of the bulk ore may vary over time as the exploitation of the site progresses. Hence, the signature of the concentrate depends on the characteristics of useful minerals, the type of deposit, the metallogenic province and the treatment the ore is subjected to. This signature is rigorously established only at a given moment of observation. In the case of base metals, traceability is the ability to find, for a given concentrate, the trace of all manufacturing stages (mineral processing) and the provenance (deposit) of all its components. The traceability of a metal concentrate would be possible to determine: 1) the province, the district, the deposit and bulk ore from which it was extracted;2) the mining company; 3) the different places where it has been stored; 4) the manipulations and the equipment used in its manufacturing (mineralurgical and metallurgical processing); 5) its transportation to its final destination; 6) its end-use; 7) its recycling; 8) its possibly reutilization, ...

A methodology for bulk ore characterization and its utilisation for discriminating mines among distinct provinces are presented in the following. It is illustrated by two applications in the Iberian Pyrite Belt and in the Urals. Here, the mineral processing issues are not taken into 
account but the reader can refer to Machault et al. (2013) for an example of metal traceability during mineral processing.

\section{Methodology of traceability in the case of base metals in Volcanogenic Massive Sulphide}

Figure 1 is a flowchart illustrating the methodological procedure followed in this study. We have selected the samples we considered as the most representative ones according to their texture and mineralogical compositions. Variability within a deposit can be significant. Comparisons are only valid at the time of sampling. That raises the problem of feasibility (which will be discussed on section 3.4). Ore samples were prepared as polished sections. The bulk ore characterization was conducted using a metallurgical microscope, a scanning electron microscope (SEM) and an electron microprobe. These techniques are used to study the textures, mineralogical composition, and chemistry of the minerals. Statistical analyses are then performed on the individual mineral phases to finally obtain an identity card of each studied ore (Figure 1). During observations, a particular attention has been paid to: the identification of characteristics microfacies, the presence of trace minerals (i.e. phases with a very low content, but which can be characteristic of a given deposit or province) and finally the minor elements contained in the "target minerals". The "target minerals" are: 1) Pyrite for its ubiquity in the studied bulk ore deposits which allows to compare bulk ores from different mines; 2) Sphalerite, which can incorporate into its structure a large number of potentially valuable elements ( $\mathrm{Ge}, \mathrm{Ag}, \mathrm{In}, \mathrm{Ga}$ ) or non-valuable elements (Fe, $\mathrm{Cd}, \mathrm{Hg}, \mathrm{Mn}, \mathrm{Sb}$ ); 3) Chalcopyrite that is repeatedly found associated with pyrite and sphalerite.

The applications of such methodology include the characterization of the ores, the deduction of the parameters that ensure ore traceability as well as the behavior of valuable elements such as Ge and In.

\section{$\underline{3.1 \text { Bulk ore characterization }}$}

We take into account the bulk ore characterization that may be considered as the "mother rock" of the deposit, since it contains the ore and the wall-rock components. In this section, we determine the mineralogical composition, the microtexture and the pseudo-paragenetic sequence.

\subsubsection{Mineralogical composition}

The mineralogical composition of each ore is represented by the relative abundance of major and minor phases, which may reflect a regional heritage. The relative abundance indicates the relative number of individuals of a given species by unit volume relative to the total number of individuals of all species. The relative abundances of target minerals according to metallographical microscope observation is indicated with the commonly used nomenclature: AA (very abundant), A (abundant), $\mathrm{F}$ (common), $\mathrm{R}$ (rare), $\mathrm{T}$ (trace). We can match this abundance code with the comparaison chart of conventional percentage estimation. In this case, very abundant (AA) is a relative abundance of more than $50 \%$; abundant (A) is a 
relative abundance between 25 and $50 \%$; common $(\mathrm{F})$ is a relative abundance between 20 and $25 \%$; rare (R) is a relative abundance between 10 and $20 \%$ and trace $(\mathrm{T})$ is a relative abundance of less than $10 \%$.

\section{$\underline{\text { 3.1.2 Microtextures }}$}

We have paid a particular attention to the investigation of microtextures. Microtextures can be very helpfull as it is not possible to reconstruct the original macrotexture for products subjected to mineralurgical processing (especially milling and grinding stages). The texture is regarded here as the study of ore grains: the mineralogical nature of grains, their sizes, their shapes and their arrangement. This study was conducted on all polished sections before and after nitric acid $\left(\mathrm{HNO}_{3}\right)$ attack using a metallographical microscope and SEM. Such an attack helps to reveal some textures in sulfides like growth bands and grain boundaries (Ramdhor, 1980).

\subsubsection{Pseudo-paragenetic sequence}

A paragenetic sequence records the successive mineralogical changes. These mineralogical changes represent a modification either in the chemical composition of the mineralizing fluid or in the local physico-chemical conditions during precipitation. The different episodes of mineralization can be replaced in their relative time sequence (Beaudoin, 2006). In this study, we have tried to establish a "pseudo paragenetic sequence." The term "pseudo" was introduced since the study of a bulk ore from a limited number of sites does not allow determination of a paragenetic sequence taking into account all the spatial variations of the mineralogical composition or the texture in a given deposit.

\section{$\underline{\text { 3.1.4 Other parameters }}$}

Other parameters could be used in traceability studies, but they were not implemented in this work. For example, the chemical composition of trace minerals in bulk ore could be a powerfull parameter but such analyses are highly dependent on the heterogeneous occurrence of trace minerals in a given bulk ore. Parameters like age, paleoenvironmental reconstruction and metal sources can be used for traceability, but these require the utilisation of conventional and unconventional stable isotope systematics. Theses techniques are not compatible with the objective of establishing a low cost and rapid traceability method.

\section{$\underline{\text { 3.2 Chemical composition of target minerals }}$}

The chemical composition of a product provides the amount or the proportion of each of its components. Using an electron microprobe analyser we have determined the chemical composition of target minerals as well as their minor elements contents. After data sorting and reduction, we computed the results to compare two samples using the non-parametric statistical methods of Kolmogorov-Smirnov and Colin White. Because of the difficulty of determining the content of minor elements with electron microprobe, we have considered these concentration values as semi-quantitative estimations of the mineral composition.

\subsubsection{Electron microprobe}


The selected analytical conditions are $25 \mathrm{kV}$ for acceleration voltage and $25 \mathrm{nA}$ for beam current. Two types of instrument standardisation have been applied depending on targeted minerals. The first one targets pyrite and chalcopyrite and the following elements are analyzed: $\mathrm{S}, \mathrm{Se}, \mathrm{Te}, \mathrm{As}, \mathrm{Sb}, \mathrm{Ni}, \mathrm{Co}, \mathrm{Fe}, \mathrm{Cu}, \mathrm{Zn}, \mathrm{Pb}, \mathrm{Bi}, \mathrm{Ag}$, In and $\mathrm{Sn}$. Counting time for major elements (Fe and $\mathrm{S}$ ) is 10 seconds while the other elements including $\mathrm{Cu}$ were counted during 20 seconds. The second standardisation procedure focuses on sphalerite. The following elements are analyzed: $\mathrm{Zn}, \mathrm{S}, \mathrm{Se}, \mathrm{Te}, \mathrm{Cu}, \mathrm{In}, \mathrm{Ge}, \mathrm{Ag}, \mathrm{Sb}, \mathrm{Cd}, \mathrm{Ga}, \mathrm{Mn}, \mathrm{Hg}$ and $\mathrm{Sn}$. Counting time of 10 seconds and 20 seconds were applied for major and minor elements, respectively. The Standards used for these analyses are shown in the table 1. All analyses were performed using the SX 50 electron microprobe at BRGM-ISTO in Orleans, on polished sections not attacked by nitric acid. To assess the reliability of our analyses, a good repeatability (Lardeau, 1989) of detection thresholds and measured contents is required. The satisfactory results obtained in measuring low-content elements allowed the acquisition of several analysis points distributed throughout very heterogeneous samples. The consistency of repeatitive analyses also attests to the reliability of the results (Machault, 2012). This method was retained because of the spot size (spatial resolution) and best calibration obtained with the electron microprobe. The spatial resolution of electron microprobe is similar to what we can be see in microscopy. It is non-destructive. Major and minor elements may be detected with high precision and reproducibility at measurement times of several minutes per spot. The electron microprobe appears more "robust" compared to other analytical techniques such as LAICPMS. The data obtained can be immediately used for mineralurgy and for understanding of ore geochemistry.

\subsubsection{Data reduction}

We preferred to remove the non-significant analyses as described below, rather than determine a limit content of detection. This enables us to be as close as possible to the analytical conditions and to facilitate comparisons between the same types of analysis performed in different laboratories. The procedure for data sorting is as following. Only the analyses with a total amount bracketed between 98 and 102\% (masses sum of elements in weight percent) have been kept. Among them, only the significant analyses for the thresholds of $95 \%$ and $99 \%$ have been selected, corresponding to error risks of $5 \%$ and $1 \%$, respectively (Poisson's law). For each element of each analysis, we perform the following tests:

For a $5 \%$ risk: $\left(P \times t_{P}\right)-\left(B G \times t_{B G}\right) \geq 2 \sqrt{\left(B G \times t_{B G}\right)}$

For a $1 \%$ risk: $\left(P \times t_{P}\right)-\left(B G \times t_{B G}\right) \geq 3 \sqrt{\left(B G \times t_{B G}\right)}$

Here $\mathrm{P}$ is the number of shots counted on the peak in counts per second, $\mathrm{t}_{\mathrm{P}}$ is the counting time on the peak, $t_{\mathrm{BG}}$ is the counting time on the background and $\mathrm{BG}$ is the number of shots counted on the background in counts per second.

Finally, to ensure the reliability of the analysis, we only take into account the elements with contents greater or equal to the limit of detection. This has been checked for each analysis and each element. The non-significant values are grouped in the class whose upper limit corresponds to the lower contents. 


\subsubsection{Comparison of two samples in the case of base metals in Volcanogenic Massive}

\section{Sulphide}

The comparaison between two samples is achieved by estimating the difference in content of a given element. The distribution of the analysed elements can be described according to the value of the coefficient of variation, using the same intervals as proposed by Kuzvart and Bohmer (1978) in their method of sampling, called the coefficient of variation (Table 2). For each element, the coefficient of variation measures the relative dispersion around the average content of the element in a mineral (Dodge, 2004). It measures like this the interest of an element in a comparison. It is defined by: $\mathrm{Cv}(\%)=\sigma / \mu$, where $\sigma$ is the standard deviation and $\mu$ is the average. The most useful elements for characterizing a deposit are those with the strongest degree of homogeneity in their distribution, in other words those with a low coefficient of variation $\mathrm{Cv}$. In this study, very irregular and extremely irregular distributions will not be used and we will only take into account the elements with very regular, regular and irregular distribution as significant parameters of the ore identity card. To compare analyses of a given mineral from two different sites, we preferred non-parametric tests, which make no assumption about the nature of the distribution of the values to be compared. Indeed, non-parametric tests are those in which the tested hypothesis (similarity of the two distributions) does not depend on the value of distribution law parameter of the populations. Hence, non-parametric tests "globally" compare the two populations (Morice, 1956). Two test examples are provided. The Kolmogorov-Smirnov test compares cumulative histograms of contents for a given element between two samples while the Colin White test compares the cumulative histograms of the content ranks for a given element between two samples. The results are considered as semi-quantitative data because of the difficulty of measuring the minor elements with an electron microprobe. For this reason non-parametric tests on all data were used (i.e. tests comparing distributions). Furthermore, the contents variability in a representative sample of the production at a given $t$ time is indicated in the identity card by the coefficient of variation (more it is low more the use of the element will discriminant).

\subsubsection{The Kolmogorov-Smirnov test}

The non-parametric Kolmogorov-Smirnov test (Press et al., 1986) used to compare two populations evaluates the homogeneity between two samples. The Kolmogorov-Smirnov test compares the distribution functions of two known samples (ech1 and ech2) of size $\mathrm{N}_{1}$ and $\mathrm{N}_{2}$ (number of analyses) for two populations from a given target mineral. There is no assumption about the nature of the distribution law (Halfon and Rosique, 1973; Scherrer et al., 1997). The maximum distance between the two function curves is denoted $\mathrm{D}_{\text {observed }}$. The more $\mathrm{D}_{\text {observed }}$ increases, the more the populations are heterogeneous (Dodge, 2004). If the tested hypothesis, namely $\mathrm{H}_{0}$ is $\mathrm{D}_{\text {observed }}<\mathrm{D} \alpha$, then the populations are homogeneous $(\mathrm{ech} 1=\mathrm{ech} 2)$ and the content in a given element does not significantly differ between the two samples for an error risk $\alpha$. Alternatively if the tested hypothesis, namely $\mathrm{H}_{1}$ is $\mathrm{D}_{\text {observed }}>\mathrm{D} \alpha$, then the populations are heterogeneous $(e c h 1 \neq e c h 2)$ and the content in a given element significantly differs between the two samples for an error risk $\alpha$. Between the two samples, we set a critical distance $(D \alpha)$ between the two representative curves of these theoretical functions, defined for the chosen $\alpha$ thresholds of 0.05 and 0.01 (representing risks of 5\% and 1\%, respectively) by: 


$$
D_{\alpha}=K_{\alpha} \sqrt{\frac{N_{1}+N_{2}}{N_{1} \times N_{2}}} \text { with } K_{\alpha}=\sqrt{\frac{1}{2}\left(-\log e^{\alpha / 2}\right)}(\text { Smirnov, 1939) }
$$

This calculation leads to cumulative histograms constructed with classes (in percent) corresponding either to quartiles $(25,50,75,100)$ or deciles $(10,20,30,40, \ldots, 90,100)$. The number of analyses to perform must be also be chosen appropriately. Ideally, the Kolmogorov-Smirnov test must match the condition provided by the simplified Sturges formula (Sturges, 1926): $\mathrm{K} \geq \sqrt{ } \mathrm{n}$. $\mathrm{K}$ is the number of classes and $\mathrm{n}$ is the number of values that are available (number of analytical data points). This determines the number of classes needed to use the test. For the calculation by quartile (4 classes), at least 16 analyses are necessary. For the calculation by decile (10 classes), at least 100 analyses are necessary. It is worth noticing that the method using the calculation by decile provides more detailed informations on the structure of the histograms.

\subsubsection{The Colin-White test}

The Colin White test examines the probability that two samples come from the same population (as the Wilcoxon test which is used to establish a 'ranking of similarity' between the sample in question and samples from a database with known origin (Gäbler et al., 2013); this test can be used after in the process to assess whether the declared origin of the sample in question is credible or not). The non-parametric Colin White test compares a criterion based on the sum of the ranks assigned to the smallest sample, to standard values from a table for risk of $1 \%$ or $5 \%$ (Morice, 1956). The succesive calculation steps are: 1) sorting the values in ascending order; 2) associating each value to a rank from 1 to $\mathrm{N}\left(\mathrm{N}=\mathrm{n}_{1}+\mathrm{n}_{2}\right.$, where $\mathrm{n}_{1}$ and $\mathrm{n}_{2}$ are the numbers of individual data from each sample being compared, and where $\mathrm{n}_{1}<\mathrm{n}_{2}$ ). For identical values, an arithmetic average is attributed; 3) calculating $S$, the sum of the ranks assigned to the $\mathrm{n}_{1}$ values (smaller sample); 4) calculating the value $\mathrm{E}(\mathrm{s})$ defined by: $\frac{n_{1}\left(n_{1}+n_{2}+1\right)}{2}$. According to the initial conditions, two cases occur.

Case 1: $\mathrm{n}_{1} \leq 15 \leq \mathrm{n}_{2} \leq 28$ (condition for the application of the test; Morice, 1956).

If $S<E(s)$, the value considered is $S$; if $S>E(s)$, the value considered is $S^{\prime}=n_{1}\left(n_{1}+n_{2}+1\right)-S$.

The bilateral test indicates that: 1) If $\mathrm{S}_{\text {( }} \mathrm{S}^{\prime}{ }^{\prime}$ ) $\leq$ the value of the $1 \%$ table, then the two distributions are almost certainly different; 2) If the value of the $1 \%$ table $<S$ (or $S^{\prime}$ ) $<$ the value of the 5\% table, then the two distributions are likely different; 3 ) If $S$ (or $S$ ') > the value of the $5 \%$ table value, then the two distributions are not significantly different.

Case 2: $15<\mathrm{n}_{1}<\mathrm{n}_{2}$ (condition for the application of the test; Morice, 1956).

Calculate the variance: $\sigma_{S}=\sqrt{\frac{n_{1} n_{2}\left(n_{1}+n_{2}+1\right)}{12}}$

Calculate the criterion: $U=\frac{S-E(s)}{\sigma_{s}}$ 
The bilateral test indicates that: 1) If $|\mathrm{U}|>$ the value of the $1 \%$ table $=2.58$, then the two distributions are almost certainly different; 2) If the value of the $5 \%$ table $=1.96<|\mathrm{U}|<$ the value of the $1 \%$ table $=2.58$, then the two distributions are likely different; 3) If $|\mathrm{U}| \leq$ the value of the $5 \%$ table $=1.96$, then the two distributions are not significantly different.

\subsection{Identity Card}

The ore identity card can be regarded as an official document, which certifies the "identity" of the ore. It must specify at least the province and if possible the original deposit. Establishing an ore identity card would help to control trade in the mineral industry. The different topics to take into account in an ore identity card are: 1) the mineralogical composition in the form of relative abundance; 2) the micro-textures of target minerals; 3) the pseudo paragenetic succession; 4) the chemical composition and the distribution of target minerals; 5) the "memory loss" of metals during mineral processing (Machault et al., 2013). The coefficient of variation of each element is given in the identity card. Other parameters may be used, but they are not implemented in this work, such as the chemical composition of trace elements and isotope systematics.

\subsection{Feasibility of the traceability method in the case of base metal in Volcanogenic Massive Sulphide}

The whole procedure may seem long and tedious. The main cost is the necessity of qualified persons to carry out this work. It should not be forgotten however that sampling to determine content is usual in mining procedures and this requires time and money. The granular material parameters obtained by sampling must be reviewed every six months or at least every year (Gy, 1988) because of the problem of representative sampling in deposits that are commonly rather heterogenous, often zoned, including stockworks, feeders, proximal and distal parts, .... It should be the same for base metals traceability. In fact, minerals chemistry (e.g. sphalerite) is particularly susceptible to change in the depositional environment (including co-existing phases, fluid composition, temperature drop, ...). Indeed, advancement in mining operations could require modifications in the identity card of bulk ores and / or concentrates. Coupling of studies to ensure traceability with those necessary to reassess the parameters of sampling in the mining industry should therefore be considered. Easy access to products and reliability of collected information are essential to the quality of the analyses. In reality, it may be difficult to sample at the desired points in mineral processing. Similarly, it may be difficult to obtain information regarding the mineral processing (planes, material flow, residence time, ...) because they are often treated as confidential.

\section{Presentation of the metallogenic context of the two studied provinces}

We limit our study to a single type of deposit: volcanogenic massive sulphide (VMS) deposits in order to consider a single metallogenic process. We chose to study bulk ores of nine deposits from two different provinces: the South-Iberian province and the Urals province. By considering deposits from different metallogenic provinces, we can evaluate the effect of 
regional heritage on the mineralogical composition and the chemistry of the bulk ore minerals.

\subsection{The South-Iberian province}

The South Iberian Pyrite Belt is located at the southern end of the Variscan Belt in the South Portuguese Zone (Lotze, 1945 ; Julivert et al., 1974 ; Onézime, 2001). Neves Corvo and Tharsis deposits (Figure 2 A) were selected for this study, because of their representability of the South Iberian Pyrite Belt. They are Late Famennian - Middle Visean in age. The NevesCorvo deposit, located in the Portuguese province of Alentejo is currently being exploited by Somincor (Sociedade Mineira de Neves-Corvo). It is the largest volcanogenic massive sulphide of $\mathrm{Cu}-\mathrm{Zn}-(\mathrm{Sn})$ in Europe and one of the largest in the world (Lundin mining, http://www.lundinmining.com/s/Neves-Corvo.asp). The mining operations of Tharsis have now stopped but it has been worked, at least, since Roman times. This site was exploited as an open pit and also underground (Leistel et al., 1994). The Compania Espanola de Minas of Tharsis has been the operator since the 1960's until mining activity stopped in 2000.

\section{$\underline{4.2}$ The Urals province}

The Urals form a linear orogenic belt extending $2500 \mathrm{~km}$ from the Aral Sea to the south, to the Novaya Zemlya island in the Arctic Ocean to the north. It results from the collision between the East European and Siberian cratons and the Kazakh micro-continent in the Late Paleozoic (Brown and Spadea, 1999; Alvarez-Brown et al., 2000). Seven deposits (Fig. 2B) were selected for this study because of their representativity of the southern Urals province: 1) The Alexandrinka deposit (Fig. 2B) is a bimodal-felsic massive sulphide deposit of Middle Devonian age (Herrington, 2000; Herrington et al., 2002, 2005). It is located in the eastern part of Magnitogorsk area in the south of the Urals (Fig. 2B) (Herrington et al., 2002; Tessalina et al., 1999); 2) The Sibay deposit (Fig. 2B) is a bimodal mafic massive sulphide deposit of middle Devonian age (Herrington, 2000; Herrington et al., 2001, 2002, 2005). It is located in the Tagil-Magnitogorsk zone in the southern Urals (Fig. 2B). Sibay is a giant massive sulphide deposit containing more than 100 million tonnes of massive sulphide (Zaykov et al., 1996). The Sibay mine is still operating today. The Bashkirienne coppersulphide company is the operator; 3) The Ivanovka deposit (Fig. 2B) is a bimodal mafic massive sulfide deposit of Silurian age; 4) The Dergamish deposit (Fig. 2B) is a mafic massive sulphide deposit of Silurian age (Zaykov et al., 2000 ; Herrington et al., 2002 ; 2005). The Re-Os isotopic analyses from Dergamish and Ivanovka deposits indicate an isochronous age of $364 \pm 10 \mathrm{Ma}$ on wall-rocks and sulphides (Tessalina et al., 2001), which is interpreted as the reset of the isotopic systems due to the Middle Devonian collision between the East European craton and the Magnitogorsk arc (Herrington et al., 2002); 5) The Yaman Kasy deposit (Fig. 2B) is a bimodal mafic massive sulphide deposit of Silurian age (K-Ar age of $421 \pm 3 \mathrm{Ma}$ on hydrothermal sericites, which can be considered as a minimum age for the deposit) (Herrington et al., 1998, 2002, 2005). It is located in Zilair and Sakmara area in Southern Urals (Fig. 2B); 6) The Mauk deposit (Fig. 2B) is a mafic pelitic massive sulphide deposit of Middle Devonian age (Maslennikov et al., 2000; Herrington, 2000; Herrington et al., 2002, 2005). It is located in the eastern part of Southern Urals (Fig. 2B); 7)The 
Safyanovka deposit (Fig. 2B) is a felsic bimodal massive sulphide deposit (Herrington et al., 2001) of Devonian age (Herrington et al., 2002). It is located in the eastern part of the Urals at the boundary between the Southern and Central Urals (Fig. 2B). The open pit of Safynovka is still operating today. The Safyanovka Copper company is the current operator.

\section{Results}

Bulk ores of deposits from the South-Iberian and Urals provinces have been characterized. It should be noted that the observations and the measured parameters and therefore the ore comparisons, have been infered only from the samples collected so that the conclusions are therefore only valid for the set of studied samples. In consequence such a traceability study requires to be updated periodically. This is particularly true for covellite, which only occurs as a feature of the Safyanovka deposit, while this mineral should be found in abundant quantities in samples from other deposits collected during the periods where supergene enrichment areas were exploited. In the rest of the article, by comparaison between deposits, the reader shall understand that the comparison is between samples taken at a given time from different deposits. Results will be expressed in qualitative or semi-quantitative form. We shall explain in more detail the case of Neves Corvo. All results can be viewed in Machault (2012). The different parameters of the identity card from bulk ore of each ore deposit allow us to differentiate deposits from a single province and also to distinguish different provinces.

\subsection{Comparison of deposits within the South Iberian province}

\section{$\underline{\text { 5.1.1 Mineralogical composition }}$}

The mineralogical compositions have been established, based on the study of the polished sections from the different bulk ores, and are compiled in Table 3 where minerals are classified according to their relative abundance. This study differentiates the two deposits by the occurrence of specific trace minerals. The presence of one or more of the following means that the bulk ore could probably be assigned to Neves Corvo (Table 3): kesterite, mawsonite, enargite, nekrasovite, gudmundite, stromeyerite, electrum, coloradoite, roquesite, clausthalite, naumannite. Conversely, the presence of one or more of the following may be a signature of Tharsis (Table 3): magnetite, mackinawite, bornite, famatinite, gold, tellurobismutite.

\section{$\underline{\text { 5.1.2 Microtextures }}$}

Several types of microtextures have been identified in each target mineral. This is compiled in Table 4 and the following provides a description as well as a tentative evolution in time of these microtextures.

\subsubsection{Pyrite}

We have distinguished four types of pyrite: 1) An euhedral pyrite grain is characterized by flat faces; 2) A colloform texture corresponds to dense aggregates of very small cells (Lebedev, 1963, 1967); 3) Pyrite agglomerates consist of a set of juxtaposed small pyrite 
grains; 4) The framboidal term was adopted by Rust (1935) to describe a particular morphology of pyrite resembling a raspberry. The framboidal texture is a spherical to subspherical aggregate of pyrite microcrystals of uniform size (Wilkin and Barnes, 1997).

Pyrite types such as colloform, agglomerates and framboidal originate from a colloidal precipitation (Papunen, 1966; Ramdohr, 1980) or the crystallization of a very saturated solution (Roedder, 1968). According to Velasco et al. (1998), in VMS type deposit, these textures correspond to early stages of pyrite deposition. Framboidal pyrite is common in the studied deposits, so a particular attention has been given, both to their relations with other sulfides, and to their evolution over time. The nitric acid attack highlights the growth forms and contacts between the different framboids. The study of framboidal pyrite grains at Neves Corvo has led us to propose an evolution in 6 stages (Figure 3A): 1) formation of primary framboidal pyrites from small cluster grains showing a concentric structure; 2) amalgamation of framboidal pyrite grains, which are rimmed by a ribbon of pyrite (with a fibroradial texture showing outward growth); 3) framboidal pyrites are encrusted by chalcopyrite, which coprecipitates with pyrite as shown by the successive layers of pyrite and chalcopyrite in fibroradial shape; 4) recrystallisation of spherulites (small round material) from the inner part of pyrite agglomerates; 5) crystallization continues with the growth of large crystals of pyrite showing outward growth on the pyrite-chalcopyrite crust previously formed; 6) brecciation and deposition of sphalerite and chalcopyrite.

For the most part, the different pyrite textures are present in both deposits, althought colloform pyrite only occurs in Neves Corvo samples (Table 4). Figure 3A compares the evolution of pyrite microtextures of Neves Corvo and Tharsis. At Tharsis, two evolution stages ( 2 and 3 stages) are missing. Hence, the evolution of framboidal pyrite can help to distinguish these two deposits of the South-Iberian province. Of course, the interpretation given to each stage may differ from a geologist to another, but this is less true for the succession of these stages.

\subsubsection{Sphalerite}

As for pyrite, we have observed several generations of sphalerite (Figure 3B): 1)The first occurrence is represented by euhedral sphalerite. This type of sphalerite is free of inclusions; 2) A second generation of euhedral sphalerite displays growth bands highlighted by chalcopyrite inclusions. Chalcopyrite inclusions in sphalerite are commonly described as "chalcopyrite disease" (Barton and Bethke, 1987). The distribution of these micrometer-scale pearl-shaped inclusions can be random or preferential (crystal defects, growth bands or microfractures) in the sphalerite crystal. In our samples, the chalcopyrite inclusions are aligned in planes forming "stripes" in sphalerite (Fig. 3B stage 2). These straight alignments are usually interpreted as the results of the reaction between iron carried by sphalerite and copper carried by a fluid flowing through microcracks (Barton and Bethke, 1987). If such mechanism applies, chalcopyrite disease can be used to reveal the presence of microcracks in the sphalerite (Fig. 3B stage 5); 3) A final type of euhedral sphalerite filling cracks is associated with chalcopyrite. It presents chalcopyrite "microcracks" revealed by nitric acid attack. These sphalerite grains are slightly stretched and are located in a chalcopyrite matrix. 
This sphalerite generation grows on euhedral and fractured pyrite grains. Fractures affecting pyrite agglomerates are filled with sphalerite (Fig. 3B Stage 5). Euhedral sphalerite exhibits growth bands highlighted by chalcopyrite inclusions and is spacially associated with euhedral pyrite, stannite and chalcopyrite.

In addition to sphalerite types, two categories of sphalerite can be distinguihed according to its association with sulfide: a) Five stages in the evolution of sphalerite associated with pyrite (Fig. 3 B) have been distinguished. The last four are distinguished by the size of the fractures that affect the preexisting sulfides. 1) in the first stage, sphalerite appears as inclusions in euhedral pyrite, suggesting that the deposition of sphalerite is anterior to contemporaneous with euhedral pyrite formation ; 2) euhedral pyrite continues to grow and still contains sphalerite inclusions ; 3) agglomerates of pyrites are broken. Micro-fractures are filled with sphalerite; 4) fractures are expanding and are filled with sphalerite; 5) fractures filled with sphalerite are large and clearly visible; b) Three stages in the evolution of sphalerite associated with chalcopyrite have been recognized (Fig. 3B): First, it shows an evolution of crusting type microfacies. Contemporaneous sphalerite, chalcopyrite and pyrite forming a micro-crusts are encrusted by sphalerite enclosing pyrite inclusions (Fig. 3B stage1); Second, it shows an evolution of sphalerite coeval with framboidal pyrite assemblages. Sphalerite and chalcopyrite first encapsulate framboidal pyrite (Fig. 3B stage 4). Then, chalcopyrite inclusions appear within sphalerite (Fig. 3B stage 5).

Figure 3B compares the evolution of sphalerite microtextures of Neves Corvo and Tharsis depending on its association with pyrite or chalcopyrite (Fig. 3B). The five evolution stages of sphalerite are visible in both deposits. For sphalerite associated with chalcopyrite, it lacks a stage at Neves Corvo (Fig. 3B stage 2) and two stages at Tharsis (Fig. 3B stage 3 and 4). For sphalerite associated with pyrite, it lacks a stage at Neves Corvo (Fig. 3B stage 5) and three stages at Tharsis (Fig. 3B stage 1,2 and 5).

\subsubsection{Pseudo-paragenetic sequence}

This study of microtextures, revealing the history of mineral formation is illustrated in Figure 4 , which presents the pseudo-paragenetic sequence for each deposit. The successions are very similar except the absence of colloform pyrite at Tharsis.

\subsubsection{Chemical composition of target minerals}

Table 5 presents the significant elements analysed by electron microprobe in target minerals of each deposit. The different types of pyrite (framboidal, agglomerate, colloform and euhedral) could not be characterised because of their very small size. Therefore, there was not enough good analyses to characterise pyrite and other target minerals according to their textures, and only the global comparison of target minerals is provided in the following. The comparison between the minor elements of pyrite from the two deposits shows that only pyrite from Neves Corvo contains $\mathrm{Cu}$ and $\mathrm{Zn}$. We can also see that the minor elements contained in the two deposits have the same type of distribution, except for Co which has a very irregular distribution at Neves Corvo and an extremely irregular one at Tharsis. Hence, $\mathrm{Cu}$ and $\mathrm{Zn}$ (as their presence or absence is a characteristic in the set of studied samples) and 
Co (as it presents difference in the nature of the distribution) are the best elements for comparing the two deposits. The comparison between the minor elements of chalcopyrite from the two deposits shows that only chalcopyrite from Neves Corvo contains $\mathrm{Pb}, \mathrm{Ag}$ and Sn. Distribution of the minor elements are very similar in the two deposits, althought As presents an extremely irregular distribution at Neves Corvo and a regular distribution at Tharsis. Hence, $\mathrm{Pb}, \mathrm{Ag}$ and $\mathrm{Sn}$ (as their presence or absence is a characteristic in the set of studied samples) and As (as it presents difference in the nature of the distribution) are the best elements for comparing the two deposits. The comparison between the minor elements of sphalerite from the two deposits shows that only sphalerite from Neves Corvo contains Se and $\mathrm{Cd}$. We can also see that the minor elements contained in the two deposits have the same type of distribution, except for $\mathrm{Fe}$, which has an irregular distribution at Neves Corvo and a regular one at Tharsis, $\mathrm{Cu}$ which has an irregular distribution at Neves Corvo and a very irregular one at Tharsis, In which has a very irregular distribution at Neves Corvo and an extremely irregular one at Tharsis and $\mathrm{Hg}$ which has an extremely irregular distribution at Neves Corvo and a very irregular one at Tharsis. Hence, Se and $\mathrm{Cd}$ (as their presence or absence is a characteristic in the set of studied samples) and $\mathrm{Fe}, \mathrm{Cu}, \mathrm{In}, \mathrm{Hg}$ (as their present difference in the nature of the distribution) are the best elements for comparing the two deposits. Figure 5 shows the comparison between elements from Neves Corvo and Tharsis. Globally, the Tharsis bulk ore contains more minor elements than the Neves Corvo one. In pyrite, $\mathrm{Pb}$ and As are enriched at Tharsis whereas Co is slightly depleted at Tharsis (Fig. 5A). Chalcopyrite is enriched in As at Tharsis with respect to Neves Corvo (Fig. 5B). Sphalerite from Tharsis contains more $\mathrm{Fe}$ and $\mathrm{Hg}$ than sphalerite from Neves Corvo (Fig. 5C). Conversely, sphalerite at Tharsis is depleted in $\mathrm{Cu}$ and In.

\subsubsection{Kolmogorov-Smirnov test}

The sample comparison between the different deposits can be regarded as a tool to check the heterogeneity of results between the two deposits. This requires a quantitative evaluation of the difference between the distributions of a given minor element in a given mineral phase from two different deposits. Regardless of the type of histograms (quartiles or deciles) and the level of risk considered (5\% or $1 \%$; see section 3.2.3.1) the following significant differences in contents between the two deposits could be used to distinguish between them (Table 6):Co, As and $\mathrm{Pb}$ for pyrite; As for chalcopyrite; $\mathrm{Hg}, \mathrm{Fe}, \mathrm{Cu}$ and $\mathrm{In}$ for sphalerite.

\section{$\underline{\text { 5.1.6 Colin-White test }}$}

In this test, the comparison between two populations does not depend on the absolute value of individual data but on the rank of element concentration after data sorting (see section 3.2.3.2). The following results have been obtained (Table 6): for pyrite, the contents in As and $\mathrm{Pb}$ almost certainly differ between the two deposits, whereas the content in Co does not significantly differ between the two deposits; for chalcopyrite, the content in As almost certainly differs between the two deposits ; and for sphalerite, the contents in $\mathrm{Hg}, \mathrm{Fe}$ and $\mathrm{Cu}$ almost certainly differ between the two deposits, whereas the content in In probably differs between the two deposits.

\subsubsection{Identity Card}


The retained parameters, characterizing Neves Corvo (Figure 6) and Tharsis bulk ores, constitute a basis for the establishement of their identity card (Figure 7), including numerous discriminating parameters.

\subsection{Comparison of deposits within the Urals Province}

\subsubsection{Mineralogical composition}

The mineralogical composition can help to distinguish the different deposits because particular minerals occur in specific deposits. The presence of tetrahedrite and / or zircon means that the bulk ore could probably be assigned to Alexandrinka. The occurrence of titanite and / or apatite, may reflect a bulk ore attributed to Mauk. Magnetite and / or siderite, only occur in the bulk ore from Sibay. The presence of marcasite seems to be a characteristic feature of the bulk ore from Dergamish. Covellite and / or tennantite, were only reported in the bulk ore from Safyanovka. Only five out of seven deposits display "characteristics" minerals, which can be used for differentiating the deposits (Table 3). As this comparison is made on samples collected at a given time in the different deposits, some differences may correspond to intrinsic characteristics between deposits (i.e. the occurrence of zircon, titanite, apatite, ...), but others may be transitory (i.e. the occurrence of covellite at Safyanovka; see section 5.1). Only a study conducted over a significant time period, providing a regular reassessment of mineralogical composition would be able to resolve the distinction between intrinsic and transitory differences.

\subsubsection{Microtextures}

Samples from Urals deposits expose the different textures of pyrite described in the South Iberian province (see section 5.1.1.2.1), except at Mauk and Ivanovka where only euhedral pyrite is reported (Table 4). Figure $8 \mathrm{~A}$ illustrates the differences in the evolution of the framboidal pyrite between Alexandrinka, Sibay, Dergamish, Yaman Kasy and Safyanovka ores. Two stages in the pyrite evolution are missing at Dergamish (stages 2 and 3), while stages 3 and 4 have not been reported at Safyanovka and Sibay, respectively. In the same way, sphalerite evolution and its association with pyrite or chalcopyrite provide a tool for differentiating the Alexandrinka and Yaman Kasy ores (Fig. 8 B). This evolution comprises five stages and sphalerite textures are similar to those described for the South Iberian province (see section 5.1.1.2.2). For sphalerite associated with pyrite, only three stages of the evolution are common to both deposits, since stages 3 and 5 are missing at Alexandrinka and Yaman Kasy, respectively. Sphalerite with chalopyrite is only reported at Alexandrinka. This comparative study provides a discriminantive parameter, to distinguish certain VMS deposits (five out of seven) of the Urals province: the evolution of framboidal pyrite. Conversely, the microtextures of other target minerals (sphalerite and chalcopyrite) do not represent a good parameter to differentiate the seven deposits from the Urals province (Table 4).

\subsubsection{Relationships between pyrite texture and the geological setting of deposits}

No particular relationships between the age of the deposits and the tectonic zone they occur in have been reported in the Urals province. It may be noted that the non-distinction of the 
deposits of the Urals according to their tectonic settings is made according to the parameters measured with the analytical methods used. For example, the Yaman Kasy, Dergamish and Ivanovka deposits are all Silurian. Yaman Kasy is located in the Sakmara zone, whereas the two others deposits are hosted within the MUNF zone. Similarly, there is no particular link between the tectonic zones where the deposits occur and the nature of their host rocks. Deposits lying in a given tectonic domain may display either similar host rocks (i.e. Sibay and Alexandrinka, Table 7) or different host rocks (i.e. Dergamish and Ivanovka, Table 7). In addition, there is no obvious relationship between the pyrite textures and the tectonic zones of the Urals province. Deposits located in a given tectonic domain may contain either pyrite with same textures (i.e. Sibay and Alexandrinka, Table 7) or pyrite with different texture (i.e. Mauk and Safyanovka, Table 7). Similarly, deposits occuring in different tectonic zones may exhibit pyrite with same (i.e. Alexandrinka and Safyanovka, Table 7) or different textures (i.e. Alexandrinka and Mauk, Table 7). Deposits with similar host rocks may contain either pyrite with same textures (i.e. Yaman Kasy and Sibay, Table 7) or pyrite with different textures (i.e. Yaman Kasy and Mauk, Table 7). Similarly, deposits with different host rocks may also display pyrite with same (i.e. Sibay and Safyanovka, Table 7) or different textures (i.e. Sibay and Ivanovka, Table 7). Hence, in the Urals province, the pyrite texture is not influenced by the age of the deposit, its host rocks or the tectonic zone in which it is located. These three characteristics related to the geological setting of the deposit cannot be considered as discriminant parameters that may be used in an identity card.

\subsubsection{Minor elements in pyrite, chalcopyrite and sphalerite}

Table 5 illustrates the differences between deposits, depending on the type of distribution for a given element, as following: For pyrite, $\mathrm{Pb}$ is the most significant element for comparing the seven deposits (Table 5). Other elements like $\mathrm{Cu}$, As and $\mathrm{Co}$ in pyrite may be used to discriminate the different deposits as they present an important range of their distribution; for chalcopyrite, $\mathrm{Pb}$ is the most significant element for comparing the seven deposits (Table 5) (except for Sibay and Dergamish); and for sphalerite, $\mathrm{Cd}$ and $\mathrm{Fe}$ are the most significant elements for comparing the four deposits (Table 5). $\mathrm{Cu}$ in sphalerite can also be used to distinguish the different deposits as it presents irregular to very irregular distribution depending on the deposits.

Figure 9 shows the comparison between elements from seven deposits of Urals. The pyrite from the Sibay and Yaman Kasy ores are depleted in minor elements compared to other deposits. In and Sn are a characteristic of Sibay pyrite, whereas Yaman Kasy pyrite contains Te (Table 5). Only sphalerite from Alexandrinka presents a significant minor element content with a relative enrichment in Sn (Table 5). Similarly, chalcopyrite from Mauk bulk ore presents higher content in Sn with respect to other deposits (Table 5).

\subsubsection{Summary of statistical tests}

In this section, we have compiled the most significant results provided by the KolmogorovSmirnov and Colin White tests (Table 6): For pyrite, both tests present very similar comparison results. The main differences are the As and $\mathrm{Cu}$ contents in pyrite, which differ (do not differ) between Alexandrinka and Safyanovka using the Kolmogorov-Smirnov test 
(the Colin White test). Similar differences between the two tests are observed for Co (between Dergamish and Ivanovka, between Ivanovka and Safyanovka, and between Ivanovka and Mauk) and for As and $\mathrm{Cu}$ (between Safyanovka and Yaman Kasy); for chalcopyrite, both tests present similar comparison results; and for sphalerite, both tests present very similar comparison results. The main differences are the following. $\mathrm{Cu}$ content in sphalerite differs (does not differ) between Alexandrinka and Sibay, Alexandrinka and Yaman Kasy and between Sibay and Yaman Kasy using the Kolmogorov-Smirnov test (the Colin White test). Similar differences between the two tests are observed for Fe (between Alexandrinka and Mauk and between Sibay and Yaman Kasy) and for Mn (between Yaman Kasy and Mauk).

In addition, both statistical tests may help to distinguish if the minor elements content of target minerals is significantly different between seven deposits. Whatever the test used (Figure 10) there are differences in the bulk ore from the seven deposits in: Co and $\mathrm{Pb}$ content in pyrite; $\mathrm{Cd}$ content in sphalerite; $\mathrm{Pb}$ and $\mathrm{Zn}$ content in chalcopyrite.

\subsubsection{Identity Card}

All the parameters obtained provide characteristics of bulk ores from differents deposits of the Urals province to establish their identity card. The pyrite microtextures is a good example of bulk ore traceability, as, in some deposits (Ivanovka and Mauk) a pyrite texture is specific to a deposit, allowing quick differentiation. The parameters we have retained are the mineralogical composition, the content of minor elements and their distribution in target minerals evaluated by using statistical tests of Kolmogorov-Smirnov and Colin White. For most of the cases, a single parameter does not provide sufficient information for discriminating the seven deposits and it is necessary to combine several parameters (Figure 10).

\section{$\underline{5.3 \text { Comparison of deposits from different provinces }}$}

In addition to the comparison between bulk ores from a given province, we have made comparisons between bulk ores from separate provinces. To compare the Urals and the South Iberian provinces bulk ores, the same methodological approach has been applied.

\section{$\underline{\text { 5.3.1 Mineralogical composition }}$}

It is possible to differentiate from a mineralogical point of view these two provinces because they do not present the same occurence of minerals, since some are specific to one province or the other. For example, the frequent and abundant minerals like covellite (with the restriction given in section 5), tennantite, siderite and marcasite only occur in the Urals province. Conversely, cassiterite, arsenopyrite, stannite, kersterite and mawsonite are only reported in the South-Iberian province (Table 3).

\section{$\underline{\text { 5.3.2 Microtextures }}$}

Similar textures of target minerals have been observed in both provinces. Only euhedral pyrite and chalcopyrites in isolated grains or in cracks are present in all the studied deposits (Table 4). Conversely, no sphalerite type is common between the nine deposits (Table 4). 


\subsubsection{Minor elements in pyrite, chalcopyrite and sphalerite}

The comparison of the minor elements content in target minerals of the two provinces, shows that only pyrite from the Urals province contains $\mathrm{Ni}$. On the other hand, $\mathrm{Zn}$ in pyrite presents similar distributions in the two provinces. Only chalcopyrite of the Urals province contains $\mathrm{Zn}$. In addition, chalcopyrite of the South Iberian province presents higher relative Ag and Sn contents. All the minor elements of chalcopyrite from the two provinces display similar types of distribution except $\mathrm{Pb}$. Only sphalerite of the Urals province contains $\mathrm{Sb}$, whereas sphalerite from the South Iberian province presents high relative Se and In contents. The distribution of minor elements in sphalerite is common between provinces except for $\mathrm{Hg}$.

Table 5 compiles the differences between provinces according to their elements distribution. For pyrite and chalcopyrite, $\mathrm{Pb}$ is the most significant element for comparing the two provinces. For sphalerite, $\mathrm{Fe}$ and $\mathrm{Cd}$ are the most significant elements for comparing the two provinces. Plots of Figure 11 illustrate the comparison of element contents between the South Iberian province and the Urals province, taking the South Iberian province as the reference. The following observations have been made: Pyrite from the Urals province presents high content in $\mathrm{Pb}, \mathrm{Zn}$ and $\mathrm{Co}$ and low content in $\mathrm{Cu}$ and $\mathrm{As}$ with respect to pyrite from the South Iberian province (Figure $11 \mathrm{~A}$ ); Chalcopyrite from the Urals province has relative high and low contents in $\mathrm{Pb}$ and $\mathrm{As}$ respectively (Figure $11 \mathrm{~B}$ ); Sphalerite from the Urals province exhibits higher (lower) contents in $\mathrm{Cu}$ and $\mathrm{Cd}(\mathrm{Fe}$ and $\mathrm{Hg}$ ) than sphalerite from the South Iberian province (Figure $11 \mathrm{C}$ ).

\subsubsection{Summary of the statistical tests}

Using the comparison of samples from different provinces, it is possible to check the heterogeneity of minor element contents between the two provinces. This involves consideration of the differences in the distribution of a given minor element in a given mineral between the two provinces. Whatever the method for calculation (quartiles or deciles), or the statistical test used (Kolmogorov-Smirnov or Colin White), the obtained results are similar (Table 6). For the three target minerals there are elements, which differ between the two provinces.

\subsubsection{Discriminative parameters betwen two provinces}

Figure 12 is a synoptic comparative table that compiles the mineralogical and chemical parameters that can be used to discriminate bulk ore from two different provinces, namely the South Iberian province and the Urals province.

\section{Discussion}

\subsection{Appropriateness of the methodological approach used}

In this study, we have established an original traceability method for base metals. The approach does not require highly sophisticated equipments and the techniques (metallographic 
microscope, SEM and electron microprobe) are easy to use Nevertheless, this method is limited by the resolution size of instrumentation, which precludes the observation and analyses of very small objects. This is particularly true when studying textures, full mineralogy and geochemistry (detection thresholds of element content). In addition, this method requires the intervention of qualified persons especially for interpretating target minerals textures (difficult to use in traceability systems made for the industry, police, customs, ...). Despite these limitations, this traceability method can be used to obtain a comprehensive identity card of the deposits, including mineralogy, texture, pseudoparagenetic sequence, minor elements content, elements distribution and results of statistical tests. Mineral chemistry is considered to be the most promising tool for provenance analyses. The number of analyses is a crucial parameter that must be considered (see section 3.2.3) as it secures the efficiency of our traceability method. In this study, for comparison of bulk ores from a given province or different provinces, the same results were obtained using quartile or decile calculation for the Kolmogorov-Smirnov test (Table 6). Although the calculation by decile provides more detailed information on the histograms shape, it requires at least 100 analyses according to the Sturges formula (see section 3.2.3.1). Such amount of individual analyses is not always available and obtaining them is often long and tedious especially when constraints on datas reduction are applied (see section 3.2.2). Therefore, the calculation by quartile, which requires less individual analyses on target minerals (16) appears to be appropriate to obtain fast, significant and reliable comparative results. Conversely, the number of analyses for performing the Colin White test is less problematic, although a minimum number of 15 analyses is necessary. The comparative results obtained from the Kolmogorov Smirnov and Colin White tests are roughly similar, regardless of the elements or considered target minerals. The rare variations are probably due to the very or extremely irregular feature of the elements distribution, as the Kolmogorov-Smirnov test is more sensitive to heterogeneity in the contents distribution because of the calculation procedure. Therefore the Colin White test appears to be the most effective test to compare the minor elements content in ore, since 1) it necessitates fewer individual data; 2) it is not influenced by the value of individual data and 3 ) it is not sensitive to element distribution heterogeneity.

\subsection{Utilisation of discriminative parameters for ore traceability}

This study has contributed to the establishment of various parameters that differ from a deposit or a province to another. Some of these parameters are discriminative but a single characteristic is generally not enough to obtain a successful discrimination of all the studied deposits. It is therefore necessary to combine parameters, as provided in the ore identity card to get a satisfactory result. In traceability studies, various ways are used to illustrate the differences between the ore deposits and therefore to visualise its source. A certificate can be establihed and attached to the commodity during its life cycle (Kimberley process). A fixed value or a range of values of a geochemical parameter (i.e. isotopic oxygen ratio) may be specific to a source location (Giuliani et al., 1998 b). In our case, there is not any unique parameter that could provide a satisfactory differentiation between the nine deposits. A flow chart (tree) using logical criteria to discriminate ore deposits can also be established (Melcher et al. $2008 \mathrm{a}$ and b), but it requires a hierarchy of the considered parameters or criteria. At this 
stage of method development, the establishment of a hierarchy between the retained characteristics, valid for all VMS deposits, seems premature. But we are able to produce flow charts for each parameter showing their discriminative or satisfactory features (Figure 13).

\subsection{Perspectives for refining the traceability method}

The described methodology in this study is only valid for bulk ore traceability but this does not correspond to the traded commodity, which is rather a concentrate. For this reason, mineral processing must be taken into account by a complementary method. The method proposed by Machault et al. (2013) for base metals has established a parameter to perform ore traceability from the bulk ore to the concentrate. This parameter «memory loss » has been included in the Neves Corvo identity card (Figure 6). The traceability refers to the situation where we have the necessary and sufficient information to determine the composition of a material throughout its production and distribution chain. The mineral processing of ore can be seen as a process in which the memory of bulk ore characteristics is lost. To calculate the "memory loss" of a given mineral processing at a given time, it is necessary to include at least the chemical compositions of the bulk ore and of the concentrate and the minimum residence time between the different steps of mineral processing. Some other ideas can be considered to refine this work: 1) improving the precision of results could be obtained by: a) having comparable sample population to study (similar amount of samples from all deposits); b) increasing the number of analyses to systematically meet the requirement of the Sturges formula for Komogorov-Smirnov test or the minimum of 15 individual analyses for the Colin White test; c) increasing the number of significant elements characterizing the mineral targets by using techniques with lower detection threshold (for the instrumentation used, the ideal conditions do not allow for a better resolution than $100 \mathrm{ppm}$ (or 0.01\%)); d) using a Seifert XRD diffractometer to automatically and quickly determine the major mineral abundance; e) using a (OQuemscan to directly obtain a mineralogical composition in terms of area percentage for the different phases; f) quantifying the relative mineral abundances using image analysis; 2) demonstrating really traceability we must clearly show that several samples, collected independently within a given deposit are not distinguishable from each other. This appears impossible given the heterogeneous nature of the ores. Therefore, it is advisable to work with concentrate samples which are collected in very large volumes of ore; 3) obtaining data at the different stages of the mineral processing to assess the "memory loss" parameter by using direct techniques of sampling (i.e. ONiton XRF portable analyser) ; 4) implementing the identity card parameters and data in an easy access database, whose structure incorporates the traceability procedure presented in this study ; 5) establishing flow charts similar to those proposed for coltan traceability (Melcher et al., 2008 a and b; Gäbler et al., 2011). This requires a hierachy of the identity card parameters, which is valid for all ores collected in VMS deposits. These types of illustrations and algorithms would represent the "holy grail" for the base metals ore traceability.

\section{$\underline{7 \text { Conclusion }}$}


This study has contributed to: 1) establish nine ore identity cards for two metallogenic provinces: Neves Corvo and Tharsis in South Iberian province; Alexandrinka, Dergamish, Yaman Kasy, Safyanovka, Ivanovka, Mauk and Sibay in the Urals province. Each identity card contains the following parameters: mineralogical composition, mineral targets microtextures, pseudo-paragenetic sequence, content and distribution of minor elements in the target minerals. It also includes the results of comparative statistical tests (KolmogorovSmirnov and Colin White tests) on minor elements content in target minerals and, when possible, the "memory loss" parameter which is a characteristic feature of mineral processing (Machault et al., 2013); 2) discriminate the bulk ores from deposits in a given province and the bulk ores between distinct provinces; 3) reveal characteristic parameter like pyrite microtexture for performing bulk ore traceability. This parameter is not influenced by the age of the deposit, the tectonics zone where the deposit is located and the nature of the rocks hosting the deposit.

Several difficulties in establishing the ore identity card have been identified: 1) the difficulty of obtaining samples the most representative of the deposit. The variability may be important because of the many types of mineralization that we can expect to find within the same deposit. The variation within a deposit is intrinsically important. We hope to have representative samples of the output of a mine at given $t$ time; 2 ) the difficulty of obtaining samples at specific stages of mineral processing from a mine currently in operation (complexity and flexibility of the processing operation, confidentiality of mineral processing). In particular, it is necessary that the ore masses sampled match with the requirement of the "sampling theory of fragmented materials" developed by Gy (1975). Similarly, some informations such as the residence time are not always available; 3 ) the investigation of target minerals microtextures due to the size of studied fragments. The problem of fragment size increases as mineral processing progresses. If the mineral size is of the same order of magnitude as the electron beam, requirements for local analyses are not achieved; 4) the minimum number of individual analyses to perform statistical tests. This number will depend on the initial condition of statistical tests as well as on conditions imposed during data reduction (see section 3.2.2); 5) the necessity of a regular review of the ore identity parameter. It has been noted that this comparative study is only valid for the given sample at the given time of sampling. Although the collected samples are representative of the mine production, frequent updates of the ore parameters are necessary, because deposits generally show geological heterogeneity. This could be combined with the regular review (every 6 months or less every year (Gy, 1988)) of parameters of sampling. This would require an easy access to the mine for sampling and an easy access to quick and low cost analytical techniques.

This method forms the basis of a necessary protocol to establish base metals ore traceability. For this, to be achieved, monitoring ore parameters is necessary throughout the life of a mine, incurring costs for analyses and competent operators. Such studies will also contribute to increase the amount of data usuable for understanding the genesis of an ore deposit and the metallogenic processes involved. The deposits are unpredictable natures. It is difficult to take into account the internal variability of the deposit. This leads to the necessity to ensure a continuous watch, which also provides a better understanding of deposits in particular on the 
valuable elements contents existing in low content. The industrial and academic communities will also benefit from traceability monitoring, which will provide regular quantitative data throughout mineral processing potentially improving its efficiency. Finally, the establishment of traceability methods based on minor element content will have an effect on mineral resource management especially for strategic (critical and valuable) elements which are sensitive to market fluctuations.

\section{Acknowledgements}

The authors are grateful for the financial support by convention $\mathrm{n}^{\circ} 200800034766$ of the "Région Centre" (France). Furthermore, we also thank Alexandre Felicio of the SOMINCOR company for Neves Corvo samples and all the complementary information provided and Valery Maslennikov for Urals samples and all the complementary information provided. We thank too Flavien Choulet and Colin Rogers for their careful proof-reading.

\section{$\underline{\text { References }}$}

Alvarez-Marron J., Brown D., Perez-Estaun A., Puchkov V., Gorozhanina Y., 2000. Accreationary complex structure and kinematics during Paleozoic arc-continent collision in the Southern Urals. Tectonophysics 325: 175-191.

Aye F., Picot P., 1976. Sur les minéraux d'étain dans les amas sulfurés massifs: découvertes récentes, inventaire, gîtologie. Compte-rendu de l'Académie des Sciences de Paris 282: 1909-1912.

Barton P.B.Jr., Bethke P.M., 1987. Chalcopyrite disease in sphalerite: pathology and epidemiology. American Mineralogist 72: 451-467.

Beaudoin G., 2006. Gîtologie et métallogénie. Manuel de cours de l’Université de Laval (Québec).

Brown D., Spadea P., 1999. Processes of forearc and accretionary complex formation during arccontinent collision in the Southern Ural Mountains. Geology 27: 649-652.

Dodge Y., 2004. Statistique, dictionnaire encyclopédique. Springer-Verlag, 662 pp.

Gäbler H-E., Rehder S., Bahr A., Melcher F., Goldmann S., 2013. Cassiterite fingerprinting by LAICP-MS. The Royal Society of Chemistry in J. Anal. At. Spectrom. 28:1247-1255.

Gäbler H-E., Melcher F., Graupner T., Bahr A., Sitnikova M., Henjes-Kunst F., Oberthür T., Brätz H., Gerdes A., 2011. Speeding Up the Analytical Workflow for Coltan Fingerprinting by an Integrated Mineral Liberation Analysis/LA-ICP-MS Approach. Geostandards and Geoanalytical research 35: 431-448.

Garcia De Miguel J.M., 1990. Mineralogía, paragénesis y sucesión de los sulfuros masivos de la Faja Pirítica en el suroeste de la Penõnsula Iberica. Bol. Geol. Min. 101: 73-105.

Giuliani G., Fallick A.E., Garnier V., France-Lanord C., Ohnenstetter D., Schwarz D., 2005. Oxygen isotope composition as a tracer for the origins of rubies and sapphires. Geology 33: 249-252. 
Giuliani G., France-Lanord C., Coget P., Schwarz D., Cheilletz A., Branquet Y., Giard D., Pavel A., Martin-Izard A., Piat D.H., 1998 a. Oxygen isotope systematic of emerald : relevance for its origin and geological significance. Mineralium Deposita 33: 513-519.

Giuliani G., France-Lanord C., Coget P., Schwarz D., Notary F., Cheilletz A., Chaussidon M., Giard D., Piat D., Bariand P., 1998 b. Vers une carte d'identité isotopique ${ }^{18} \mathrm{O} /{ }^{16} 0$ des émeraudes naturelles et synthétiques. Association française de gemmologie. L'émeraude, connaissances actuelles et prospectives, p. 55-70.

Gy P., 1988. Hétérogénéité, échantillonnage, homogénéisation. Mason, Paris, 608 pp.

Gy P., 1975. Théorie et pratique de l'échantillonnage des matières morcelées. Éditions P.G., 597 pp.

Halfon J., Rosique A., 1973. Comparaison des éléments «en traces » dans les blendes du filon et du stratiforme de Saint-Salvy (Tarn). Bulletin du BRGM 5: 403-432.

Herrington R.J., Maslennikov V., Zaykov V., Seravkin I., Kosarev A., Buschmannd B., Orgeval J.J., Holland N., Tessalina S., Nimis P., Armstrong R., 2005. Classification of VMS deposits: Lessons from the South Uralides. Ore Geology Reviews 27: 203-237.

Herrington R.J., Smith M., Maslennikov V., Belogub E., Armstrong R., 2002. A short review of Paleozoic hydrothermal magnetite iron-oxide deposits of the south and central Urals and their geological setting. In: Porter T.M., (ed.) Hydrothermal Iron Oxide Copper-Gold and Related Deposits: A Global Perspective, vol.2. PGC Publishing, South Australia, p. 243-253.

Herrington R.J., Smith M.P., Armstrong R.N., Maslennikov V.V., Belogub E., 2001. Short review of iron oxide deposits in the Palaeozoic of the south Urals. AMF Monograph Iron-Oxide Copper Gold Deposits Vol 2.

Herrington R.J., 2000. Urals province. In: Large R., Blundell D., (ed.) Database on Global VMS districts. Codes-GEODE. University of Tasmania, Australia, p. 58-76.

Herrington R.J., Armstrong R.N., Zaykov V.V., Maslennikov V.V., Tessalina S.G., Orgeval J.J., Taylor R.N.A., 1998. Massive sulfide deposits in the South Urals: geological setting within the framework of the Uralide Orogen. In: Brown D., Juhlin C., Puchkov V., (eds.) Mountain Building in the Uralides: Pangea to Present. American Geophysical Union, Geophysical Monograph 132: 155182.

Julivert M., Fontboté J.M., Ribeiro A., Conde L., 1974. Mapa tectonico de la Peninsula Iberica y Baleares. Ser. Publ. Ministerio de Industria, Madrid.

Koroteev V.A., De Boorder H., Necheukhin V.M., Sazonov V.N., 1997. Geodynamic setting of the mineral deposits of the Urals. Tectonophysics 276: 291-300.

Kuma J.S., Yendaw J.A., 2010. The Need to Regularise Activities of Illegal Small-Scale Mining in Ghana. A Focus on the Tarkwa-Dunkwa Highway. International Journal of Geosciences 1: 113-120.

Kuzvart M., Bohmer M., 1978. Prospecting and exploration of mineral deposit. Academia Prague, 431 pp.

Kvarntröm B., Oghazi P., 2008. Methods for traceability in continuous processes - Experience from an iron ore refinement process. Minerals Engineering 21: 720-730. 
Lardeau M., 1989. Minéralogie et pétrogenèse du minerai sulfuré du gisement volcano-sédimentaire à Zn-Cu-Ba-(Pa-Ag) de Chessy-les-Mines (Rhône). Application à l'étude des amas sulfurés métamorphisés. Documents du BRGM n ${ }^{\circ} 166$.

Lebedev L.M., 1967. Metacolloid in Endogenic Deposits. Plenum Press, New York, 298 pp.

Lebedev L.M., 1963. Installation for measuring dynamic parameters of polymerized materials. In: Measurement techniques 6, p. 911-915

Leistel J.M., Bonijoly D., Braux C., Freyssinet P., Kosakevitch A., Leca X., Lescuyer J.L., Marcoux E., Milesi J.P., Piantone P., Sobol F., Tegyey M., Thiéblemont D., Viallefond L., 1994. The massive sulphide deposits of the South Iberian Pyrite Province: geological setting and exploration criteria. Documents BRGM 234, 236 pp.

Lotze F., 1945. Zur Gliederung der Varisciden der Iberischen Meseta. Geotecktonische Forsch 6: 7892.

Machault J., Barbanson L., Augé T., Bailly L., Felicio A., 2013. „Memory loss“ during mineral processing: Application to base metals traceability. Minerals Engineering 46-47: 112-118.

Machault J., 2012. Paramètres minéralogiques et microtexturaux utilisables dans les études de traçabilité des minerais métalliques. Thèse de $3^{3 \text { ème }}$ cycle de l'Université d'Orléans, 388 pp.

Marcoux E., Moëlo Y., Leistel J.M., 1996. Bismuth and cobalt minerals as indicators of stringer zones to massive suphide deposits, Iberian Pyrite Belt. Mineralium Deposita 31: 1-26.

Maslennikov V.V., Zaykov V.V., Zaykova E.V., 2000. Paleohydrothermal Fields and Ore Formation Conditions at Massive Sulfide Deposits in the Uralian Paleoocean. In: Mezhelovsky N.V., Morozov A.F., Gusev G.S., Popov V.S., (eds.) Geodynamics and Metallogeny: Theory and Implications for Applied Geology. Ministry of Natural Resources of the Russian Federation and GEOKART Ldt., Moscow, p. 339-359.

Melcher F., Graupner T., Gäbler H-E., Sitnikova M., Henjes-Kunst F., Oberthür T., Gerbes A., Dewaele S., 2013. Tantalum-(niobium-tin) mineralisation in African pegmatites and rare metal granites: Constraints from Ta-Nb oxide mineralogy, geochemistry and $\mathrm{U}-\mathrm{Pb}$ geochronology. Ore Geology Reviews, http://dx.doi.org/10.1016/j.oregeorev.2013.09.003.

Melcher F., Graupner T., Henjes-Kunst F., Oberthür T., Sitnikova M., Gäbler E., Gerdes A., Brätz H., Davis D., Dewaele S., 2008a. Analytical Fingerprint of Columbite-Tantalite (Coltan) Mineralisation in Pegmatites - Focus on Africa. Ninthe International Congress for Applied Mineralogy Brisbane, QLD, 8-10 September.

Melcher F., Sitnikova M.A., Graupner T., Martin N., Oberthür T., Henjes-Kunst F., Gäbler E., Gerdes A., Brätz H., Davis D.W., Dewaele S., 2008b. Fingerprinting of conflict minerals: columbite-tantalite (“coltan") ores. SGA News 23: 6-14.

Morice E., 1956. Quelques tests non paramétriques. Revue de statistique appliquée 4: 75-107.

Onézime J., 2001. Environnement structural et géodynamique des minéralisations de la Ceinture Pyriteuse Sud-Ibérique: leur place dans l'évolution hercynienne. Thèse de $3^{\text {ème }}$ cycle de l'Université d'Orléans, 268 pp. 
Papunen H., 1966. Framboidal textures of the pyritic layer found in a peat bog in S.E. Finland. Bull. Comm. Geol. Finlande 222: 117-125.

Press W.H., Flannery B.P., Teukolsky S.A., Vetterling W.T., 1986. Numerical Recipes, The Art of Scientic Computing. Cambridge University Press, 818 pp.

Ramdohr P., 1980. The ore minerals and their intergrowths. International Series in Earth Sciences 35. Pergamon, $1269 \mathrm{pp}$.

Roedder E., 1968. The noncolloidal origin of «colloform» textures in sphalerite ores. Economic geology 63: 451-471.

Rust G.W., 1935. Colloïdal primary copper ores at cornwall mines, southeastern Missouri. J. Geol. 43: 398-426.

Savu-Krohn C., Randtitsch G., Auer P., Melcher F., Graupner T., 2011. Geochemical Fingerprinting of Coltan Ores by Machine Learning on Uneven Datasets. Natural Resources Research 20: 177-191.

Sherrer, Legendre P., Borcard D., 1997. Statistical comparison of univariate tests of homogeneity of variance. $393 \mathrm{pp}$.

Smirnov N. V., 1939). On the estimation of the discrepancy between empirical curves of distribution for two independent samples (Russian). Bulletin of Moscow University, 2 : 3-1

Sturges H., 1926. The choice of a class-interval. Journal of American statistical association 21: 65-66.

Tessalina S.G., Zaykov V.V., Orgeval J.J., Augé T., Omenetto P., 2001. Mafic-ultramafic hosted massive sulphide deposits in Southern Urals (Russia). In: Piestrzynski et al., (eds.) Mineral Deposits at the Beginning of the $21^{\text {st }}$ Century. Swets and Zeitlinger, Lisse, p. 353-356.

Tessalina S.G., Maslennikov V.V., Zaykov V.V., Orgeval J.J., 1999. Ore facies of the Alexandrinka massive suphide deposit, South Urals. Proceedings of the Fifth Biennal SGA Meeting and the Tenth Quadrennial IAGOD Symposium, London, United Kingdom, 22-25 August 1999, A.A. Balkena, Rotterdam, p. 601-604.

Velasco F., Sanchez-España J., Boyce A.J., Fallick A.E., Sáez G.R., Almodóvar G.R., 1998. A new sulphur isotopic study of some Iberian pyrite belt deposits: Evidence of a textural control on suphur isotope composition. Mineralium Deposita 34: 4-18.

Wilkin R.T., Barnes H.L., 1997. Formation processes of framboidal pyrite. Geochimica et Cosmochimica Acta 61: 323-339.

Zaykov V.V., Zoyakova E.V., Maslennikov V.V., 2000. Volcanic complexes and ore mineralization in spreading basins of the southern urals. In: MESHElOVSKY N.V. ET AL., (eds.) Geodynamics and Metallogeny. Nauka Publishing House, Moscow, p. 315-337.

Zaykov V.V., Maslennikov V.V.,Zoyakova E.V., Herrington R.J., 1996. Hydrothermal activity and segmentation in the Magnitogorsk-West Mugodjarian zone on the margins of the Urals paleoocean. In: MacLeod C.J., Tyler P.A., Walker C.L., (eds.) Tectonic, Magmatic, Hydrothermal and Biological Segmentation of the Mid Ocean Ridges. Geological Society of London 118: 199-210. 


\section{Figure captions}

Figure 1: Organization chart of the method used for establishing identity cards.

Figure 2: A) Map of the location of Neves Corvo and Tharsis deposits (by Oliveira, 1990); B) Structural diagram of the southern part of the Urals with location of studied deposits (by Herrington et al. 2002).

Figure 3: A) Framboidal pyrites evolution from Neves Corvo and Tharsis deposits (pictures taken throuph a metallographic microscope) Stage 1- framboidal pyrite, Stage 2- crusting fribro-radial structure, Stage 3- crusting with chalcopyrite - coprecipitation pyritechalcopyrite, Stage 4- disappearence of spherulites in the inner part, Stage 5- cristallization 
continues - growth of large crystals, Stage 6- brecciation - deposition of other sulphides; B) Sphalerites associated with pyrite and chalcopyrite from Neves Corvo and Tharsis bulk ore (pictures taken through a metallographic microscope) Stage 1- sphalerite, chalcopyrite, pyrite (micro-crusting), Stage 2- the pyrite growth, Stage 3- microfracturing - filling by sphalerite, Stage 4- filling continues, Stage 5- chalcopyrite inclusions in sphalerite. The scale shown is valid throughout the figure.

Figure 4: Pseudo-paragenetic sequence of different deposits from South-Iberian and Urals provinces.

Figure 5: Graphics showing the ratio of element contents of A) pyrites, B) chalcopyrites and C) sphalerites from the Tharsis and Neves Corvo bulk ore (sulfides of this deposit are used as reference). Error bars correspond to twice the value of the standard deviation.

Figure 6: Identity Card of Neves Corvo. Experimental memory loss refers to a characteristic of the mineral processing (Machault et al., 2013).

Figure 7: Parameters for discriminating Neves Corvo to Tharsis.

Figure 8: A) Framboidal pyrites evolution from Alexandrinka, Yaman Kasy, Dergamish, Safyanovka and Sibay deposits (pictures taken through a metallographic microscope) Stage 1small primary framboidal pyrites, Stage 2- crusting - fibro-radial structure, Stage 3- crusting with chalcopyrite - coprecipitation pyrite-chalcopyrite, Stage 4- disappearence of spherulites in the inner part, Stage 5- cristallization continues - growth of large crystals, Stage 6brecciation - deposition of other sulphides; B) Sphalerite associated with pyrite and chalcopyrite evolution from Alexandrinka and Yaman Kasy bulk ore Stage 1- sphalerite, chalcopyrite, pyrite (micro-crusting), Stage 2- the pyrite growth, Stage 3- microfracturing filling by sphalerite, Stage 4- filling continues, Stage 5- chalcopyrite inclusions in sphalerite.

Figure 9: Graphics showing the ratio of element contents of A) pyrites, B) chalcopyrites and C) sphalerites from different deposits of the Urals province bulk ore (Alexandrinka sulfides are used as reference). Error bars correspond to twice the value of the standard deviation.

Figure 10: Parameters for discriminating seven deposits of the Urals province.

Figure 11: Graphics illustrating the element contents of A) the pyrite, B) the chalcopyrite and C) the sphalerite from bulk ore between the South-Iberian province (this province is used as a reference) and the Urals province. Error bars correspond to twice the value of the standard deviation.

Figure 12: Parameters discriminating between the South-Iberian province and the Urals province.

Figure 13: Tree parameters: A) microtextures to differentiate deposits; B) mineralogical composition; C) minor elements content in pyrites. Deposits are: NC: Neves Corvo, THA: Tharsis, A: Alexandrinka, SB: Sibay, D: Dergamish, YK: Yaman Kasy, S: Safyanovka, I: Ivanovka, M: Mauk. 


\begin{tabular}{|c|c|c|}
\hline \multirow[b]{2}{*}{ Elements } & \multicolumn{2}{|c|}{ Standards } \\
\hline & "Pyrite" standardisation & "Sphalerite" standardisation \\
\hline $\mathrm{Fe}$ & Pyrite & Pyrite \\
\hline S & Pyrite & Sphalerite/Pyrite \\
\hline $\mathrm{Se}$ & Metal Se & Metal Se \\
\hline As & As & \\
\hline $\mathrm{Zn}$ & Sphalerite & Sphalerite/Pyrite \\
\hline $\mathrm{Ni}$ & Metal Ni & \\
\hline $\mathrm{Pb}$ & $\mathrm{PbS}$ & \\
\hline $\mathrm{Ag}$ & Metal Ag & Metal Ag \\
\hline In & Roquesite & Roquesite \\
\hline $\mathrm{Cu}$ & Roquesite & Roquesite \\
\hline $\mathrm{Bi}$ & $\mathrm{Bi} 1913 \mathrm{~S} 27^{*}$ & \\
\hline Co & Metal Co & \\
\hline $\mathrm{Te}$ & $\mathrm{Te}$ & \\
\hline $\mathrm{Sb}$ & $\mathrm{Sb}_{2} \mathrm{~S}_{3}$ & $\mathrm{Sb}_{2} \mathrm{~S}_{3}$ \\
\hline Sn & Cassiterite & Cassiterite \\
\hline $\mathrm{Ga}$ & & AsGa \\
\hline $\mathrm{Ge}$ & & $\mathrm{Ge}$ \\
\hline $\mathrm{Hg}$ & & $\mathrm{HgS}$ \\
\hline $\mathrm{Cd}$ & & Metal Cd \\
\hline $\mathrm{Mn}$ & & $\mathrm{MnTiO}_{3}$ \\
\hline $\mathrm{Te}$ & & $\mathrm{Te}$ \\
\hline
\end{tabular}

Table 1: Standards used for the electron microprobe. * refers to Miehe, G. and Kupcik, V. (1971), Die Kristallstruktur des $\mathrm{Bi}\left(\mathrm{Bi}_{2} \mathrm{~S}_{3}\right)_{9} \mathrm{I}_{3}$, Naturwissenschaften 58, 219.

\begin{tabular}{cc}
\hline Analyzed elements distribution & Coefficient of variation $\mathbf{C v}$ \\
\hline Very regular & $\leq 20 \%$ \\
Regular & $20-40 \%$ \\
Irregular & $40-80 \%$ \\
Very irregular & $80-150 \%$ \\
Extremely irregular & $>150 \%$ \\
\hline
\end{tabular}

Table 2: Characterization of the distribution of analyzed elements by value of the coefficient of variation (by Kuzvart and Bohmer, 1978). 


\begin{tabular}{|c|c|c|c|c|c|}
\hline Deposits & $\begin{array}{c}\mathbf{n} \\
\text { Samples number }\end{array}$ & $\begin{array}{c}\text { AA } \\
\text { Very abundant }\end{array}$ & $\begin{array}{c}\text { A } \\
\text { Abundant }\end{array}$ & $\begin{array}{c}F \\
\text { Frequent }\end{array}$ & $\begin{array}{c}\mathbf{R} \\
\text { Rare + traces }\end{array}$ \\
\hline \multirow[t]{15}{*}{ Neves Corvo } & 13 & Pyrite & Cassiterite & Arsenopyrite & Pyrrhotite $^{1}$ \\
\hline & & & Sphalerite & Stannite & Bi minerals ${ }^{1}$ \\
\hline & & & Chalcopyrite & Kesterite $^{1}$ & Meneghinite ${ }^{1}$ \\
\hline & & & Tetraedrite & Mawsonite $^{1}$ & Bournonite $^{1}$ \\
\hline & & & Galena $^{1}$ & & Co minerals ${ }^{1}$ \\
\hline & & & & & Cubanite $^{1}$ \\
\hline & & & & & Enargite $^{1}$ \\
\hline & & & & & Nekrasovite $^{1}$ \\
\hline & & & & & Gudmundite $^{1}$ \\
\hline & & & & & Stromeyerite $^{1}$ \\
\hline & & & & & Electrum ${ }^{1}$ \\
\hline & & & & & Coloradoite $^{1}$ \\
\hline & & & & & Roquesite $^{1}$ \\
\hline & & & & & Clausthalite $^{1}$ \\
\hline & & & & & Naumannite $^{1}$ \\
\hline \multirow[t]{12}{*}{ Tharsis } & 14 & Pyrite & Cassiterite $^{1}$ & Meneghinite $^{1}$ & Pyrrhotite $^{2}$ \\
\hline & & Sphalerite & Chalcopyrite & Bournonite $^{1}$ & Cubanite $^{1}$ \\
\hline & & & Galena & & Tetraedrite $^{1}$ \\
\hline & & & Magnetite $^{1}$ & & Arsenopyrite \\
\hline & & & & & Stannite $^{3}$ \\
\hline & & & & & Mackinawite $^{1}$ \\
\hline & & & & & Bornite $^{3}$ \\
\hline & & & & & Famatinite $^{1}$ \\
\hline & & & & & Cobaltite \\
\hline & & & & & Bismuthinite \\
\hline & & & & & Or \\
\hline & & & & & Tellurobismutite \\
\hline \multirow[t]{4}{*}{ Alexandrinka } & 15 & Pyrite & Sphalerite & Barytine & Tetraedrite \\
\hline & & & Chalcopyrite & Bornite $^{4}$ & Galena \\
\hline & & & & & IImenite \\
\hline & & & & & Zircon \\
\hline \multirow[t]{3}{*}{ Sibay } & 2 & Pyrite & Chalcopyrite & Sphalerite & Pyrrhotite \\
\hline & & & & Magnetite $^{4}$ & Galena \\
\hline & & & & Siderite $^{4}$ & \\
\hline Ivanovka & 1 & Pyrite & Chalcopyrite & Pyrrhotite & Baryte \\
\hline \multirow[t]{4}{*}{ Dergamish } & 1 & Pyrite & & Chalcopyrite & Iron oxyde \\
\hline & & & & Sphalerite & \\
\hline & & & & Marcassite $^{5}$ & \\
\hline & & & & Pyrrhotite $^{5}$ & \\
\hline \multirow[t]{2}{*}{ Yaman Kasy } & 4 & Pyrite & & Chalcopyrite & Baryte \\
\hline & & & & Sphalerite & Galena \\
\hline \multirow[t]{5}{*}{ Mauk } & 3 & Pyrite & & Chalcopyrite & Sphalerite \\
\hline & & & & & Iron oxyde \\
\hline & & & & & Ilmenite \\
\hline & & & & & Titanite \\
\hline & & & & & Apatite \\
\hline \multirow[t]{3}{*}{ Safyanovka } & 1 & Pyrite & Chalcopyrite & Covellite & Galena \\
\hline & & & & Sphalerite $^{6}$ & \\
\hline & & & & Tennantite $^{6}$ & \\
\hline
\end{tabular}

Table 3: Chemical composition of opac minerals from deposits of the South-Iberian and Urals provinces. Minerals with a numerical suffix have not been observed, but are inferred from: 1 Marcoux, Moëlo et Leistel, 1996; 2 Aye et Picot, 1976; 3 Garcia de Miguel, 1990; 4 Herrington, 2000; 5 Zaykov et al., 2000; 6 Koroteev et al., 1997. 
Neves Corvo Tharsis Alexandrinka Sibay Ivanovka Dergamish Yaman Kasy Mauk Safyanovka

Pyrite

Euhedral pyrite

Colloform pyrite

Agglomerate of pyrites

Framboidal pyrite

$x$

Euhedral sphalerite

Euhedral sphalerite with growth bands highlighted by chalcopyrite inclusions

Sphalerite associated with chalcopyrite

Sphalerite associated with pyrite

$\begin{array}{lll}x & x & x \\ x & & x \\ x & x & x \\ x & x & x\end{array}$

$x$
$x$
$x$
$x$

\begin{tabular}{|c|c|c|}
\hline$x$ & $x$ & $x$ \\
\hline x & & \\
\hline$x$ & & $x$ \\
\hline$x$ & & $x$ \\
\hline
\end{tabular}

$\begin{array}{ccc}x & x & x \\ x & & x \\ x & & x \\ x & & x\end{array}$

Chalcopyrite

Massive chalcopyrite

$\begin{array}{ll}x & x \\ x & x\end{array}$

$x \quad x \quad x \quad x$

Chalcopyrite grains isolated

$x \quad x$

$x \quad x$

$x$

Table 4: Microtextures of deposits from South-Iberian and Urals provinces. X indicates the presence of this type of microtexture.

\begin{tabular}{|c|c|c|c|c|c|c|c|c|c|c|c|}
\hline & Neves Corvo & Tharsis & IPB & Alxandrinka & Sibay & Ivanovka & Dergamish & Yaman Kasy & Mauk & Safyanovka & Urals \\
\hline \multicolumn{12}{|l|}{ Pyrite } \\
\hline$n$ & 142 & 27 & 169 & 134 & 30 & 7 & 25 & 39 & 29 & 21 & 285 \\
\hline ngr & 47 & 19 & 66 & 114 & 25 & 7 & 10 & 35 & 25 & 14 & 230 \\
\hline \multicolumn{12}{|l|}{ Distribution } \\
\hline very regular & & & & $\mathrm{Pb}$ & & $\mathrm{Ni}, \mathrm{Co}$ & $\mathrm{Pb}$ & $\mathrm{Pb}$ & $\mathrm{Pb}$ & $\mathrm{Pb}$ & \\
\hline regular & & & & & $\mathrm{Pb}$ & & & & Co & & $\mathrm{Pb}$ \\
\hline irregular & As & As & As & & & & & & & & \\
\hline very irregular & $\mathrm{Pb}, \mathrm{Cu}, \mathrm{Co}$ & & $\mathrm{Pb}, \mathrm{Cu}, \mathrm{Co}$ & & & & Co & & & As, $\mathrm{Cu}, \mathrm{Co}$ & \\
\hline extremely irregular & $\mathrm{Ag}, \mathrm{Sb}, \mathrm{Zn}, \mathrm{Sn}$ & Co & $\mathrm{Zn}$ & As, $\mathrm{Cu}, \mathrm{Zn}, \mathrm{Sb}, \mathrm{Ni}, \mathrm{Co}$ & As, $\mathrm{Cu}, \mathrm{Zn}, \mathrm{In}, \mathrm{Sn}, \mathrm{Co}$ & & $\mathrm{Cu}, \mathrm{Sb}$ & $\mathrm{As}, \mathrm{Te}, \mathrm{Cu}, \mathrm{Zn}, \mathrm{Co}$ & & $\mathrm{Zn}, \mathrm{Sb}$ & $\mathrm{Cu}, \mathrm{As}, \mathrm{Zn}, \mathrm{Co}, \mathrm{Ni}$ \\
\hline \multicolumn{12}{|l|}{ Sphalérite } \\
\hline$n$ & 80 & 38 & 118 & 101 & 12 & & & 31 & 2 & & 146 \\
\hline $\mathrm{ngr}$ & 44 & 10 & 54 & 90 & 12 & & & 22 & 2 & & 126 \\
\hline \multicolumn{12}{|l|}{ Distribution } \\
\hline very regular & & & & & & & & & $\mathrm{Fe}$ & & \\
\hline regular & & $\mathrm{Fe}$ & & Cd & & & & $\mathrm{Cd}$ & & & \\
\hline irregular & $\mathrm{Fe}, \mathrm{Cu}$ & & $\mathrm{Fe}, \mathrm{Cu}$ & & $\mathrm{Fe}, \mathrm{Cu}, \mathrm{Cd}$ & & & $\mathrm{Fe}$ & & & $\mathrm{Cd}$ \\
\hline very irregular & In, Se & $\mathrm{Cu}, \mathrm{Hg}$ & In & $\mathrm{Cu}, \mathrm{Fe}$ & $\mathrm{Hg}$ & & & $\mathrm{Cu}$ & & & \\
\hline extremely irregular & $\mathrm{Cd}, \mathrm{Hg}$ & In & $\mathrm{Se}, \mathrm{Hg}, \mathrm{Cd}$ & $\mathrm{Sb}, \mathrm{Hg}, \mathrm{Se}, \mathrm{Sn}, \mathrm{Ag}$ & & & & $\mathrm{Mn}$ & & & $\mathrm{Fe}, \mathrm{Cu}, \mathrm{Sb}, \mathrm{Hg}$ \\
\hline \multicolumn{12}{|l|}{ Chalcopyrite } \\
\hline$n$ & 68 & 5 & 73 & 117 & 21 & 12 & 8 & 29 & 29 & 5 & 221 \\
\hline $\mathrm{ngr}$ & 25 & 4 & 29 & 89 & 14 & 7 & 8 & 18 & 24 & 5 & 165 \\
\hline \multicolumn{12}{|l|}{ Distribution } \\
\hline very regular & & & & $\mathrm{Pb}$ & & & & $\mathrm{Pb}$ & & $\mathrm{Pb}$ & \\
\hline regular & & As & & & & & & & & & \\
\hline irregular & & & & & & & & & & & $\mathrm{Pb}$ \\
\hline very irregular & & & & & & $\mathrm{Pb}, \mathrm{Zn}$ & & & $\mathrm{Zn}$ & & \\
\hline extremely irregular & $\mathrm{Pb}, \mathrm{Ag}, \mathrm{As}, \mathrm{Sn}$ & & $\mathrm{Pb}, \mathrm{Ag}, \mathrm{As}, \mathrm{Sn}$ & As, $\mathrm{Zn}$ & $\mathrm{Zn}$ & & & As, $\mathrm{Zn}$ & $\mathrm{Pb}, \mathrm{Sn}$ & & As, $\mathrm{Zn}$ \\
\hline
\end{tabular}

Table 5: Minor elements and distribution of these elements in deposits of the South-Iberian and Urals provinces. $\mathrm{n}$ indicates the number of analyses and ngr the number of mineral grains analysed. 


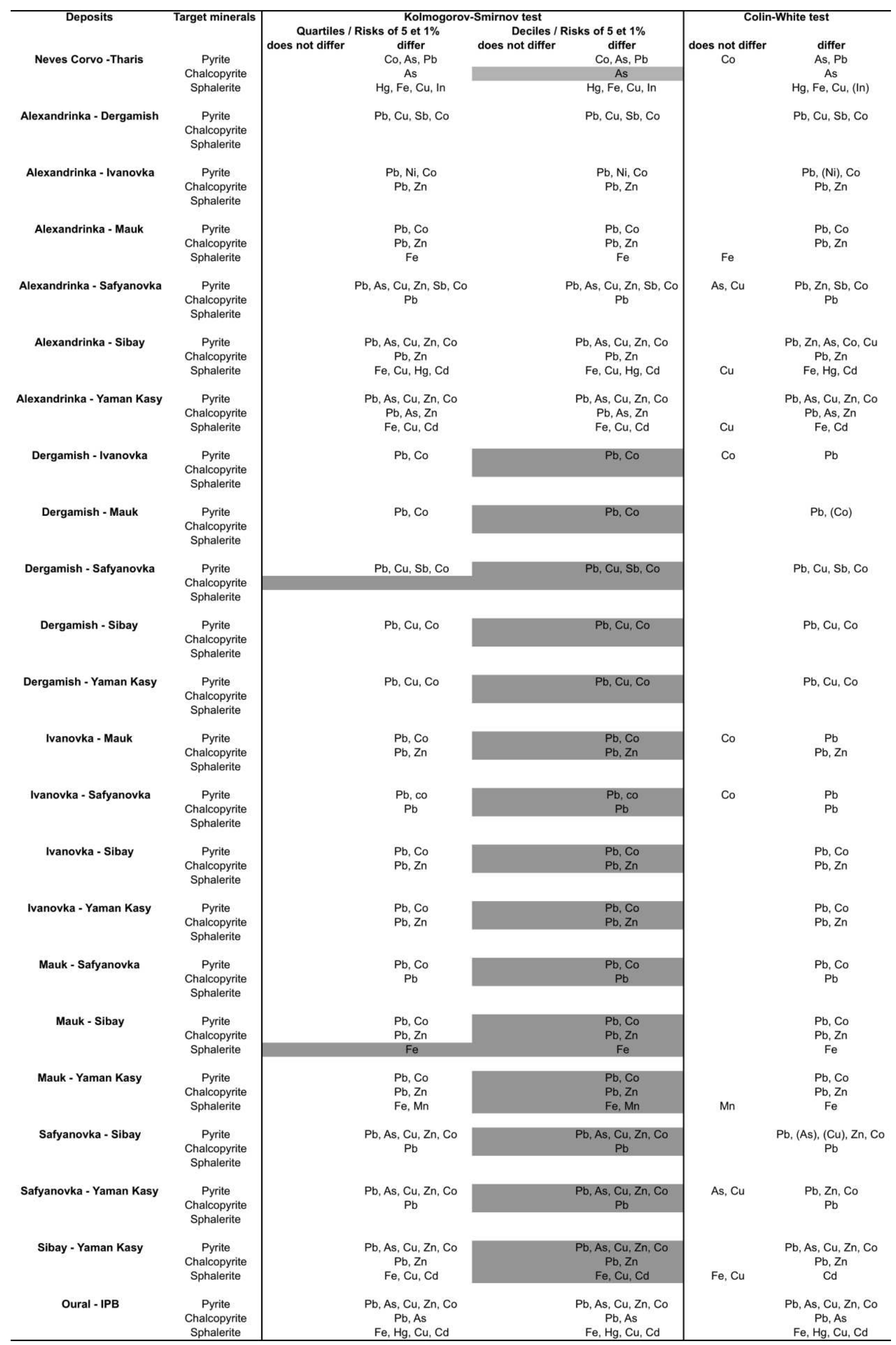


Table 6: Kolmogorov-Smirnov and Colin White statistical tests. Shaded boxes correspond to $\mathrm{K}<\sqrt{\mathrm{n}}$ (see Sturges formula).

\begin{tabular}{|c|c|c|c|c|c|c|c|}
\hline \multirow[b]{2}{*}{ Deposit } & \multirow[b]{2}{*}{ Age } & \multirow[b]{2}{*}{ Structural domain } & \multirow[b]{2}{*}{ Volcanics host rocks } & \multicolumn{4}{|c|}{ Types of pyrite } \\
\hline & & & & Agglomerates & Euhedrals & Framboidals & Colloforms \\
\hline Yaman Kasy & Silurian & Sakmara & bimodal magmatism: basalt / andesite / dacite (tholeiitic evolution) & $\mathrm{x}$ & $\mathrm{x}$ & $\mathrm{x}$ & $\mathrm{x}$ \\
\hline Dergamish & Silurian & MUNF & Serpentinite and gabbro, tholeiitic basalt to boninitic & $\mathrm{x}$ & $\mathrm{x}$ & $\mathrm{x}$ & \\
\hline Ivanovka & Silurian & MUNF & contact between the ultramafic rocks and the Silurian basalt formation & & $\mathrm{x}$ & & \\
\hline Sibay & Middle devonian & Magnitogorsk & bimodal magmatism: basalt / andesite / dacite (tholeiitic evolution) & $\mathrm{x}$ & $\mathrm{x}$ & $\mathrm{x}$ & $\mathrm{x}$ \\
\hline Alexandrinka & Middle devonian & Magnitogorsk & Andesites and dacites & $\mathrm{x}$ & $\mathrm{x}$ & $\mathrm{x}$ & $\mathrm{x}$ \\
\hline Mauk & Middle devonian & East of Urals & Metasediments and basaltic (tholeiitic) & & $\mathrm{x}$ & & \\
\hline Safyanovka & Devonian & East of Urals & Felsic and mafic rocks & $x$ & $x$ & $x$ & $x$ \\
\hline
\end{tabular}

Table 7: Comparison to the tectonic setting, age and different textures of pyrite in different deposits from Urals province. $\mathrm{X}$ indicates the presence of this type of pyrite. 


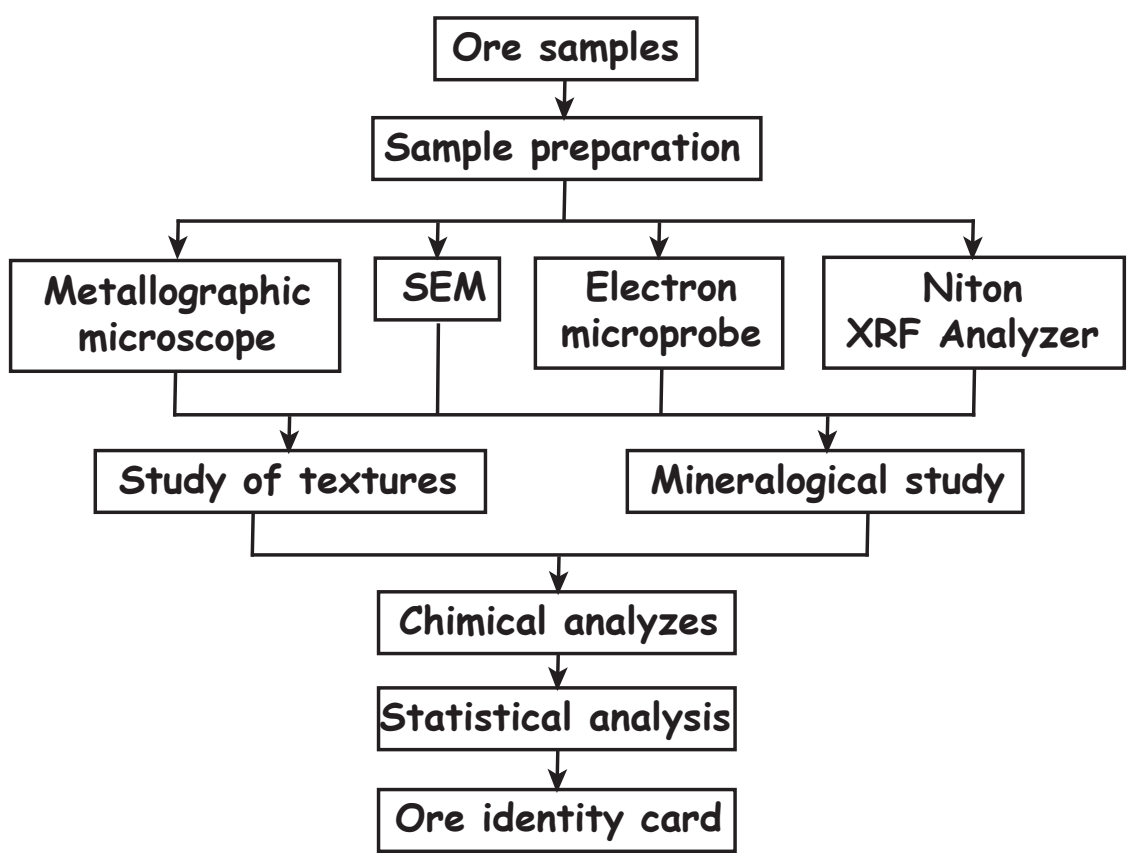

Figure 1 


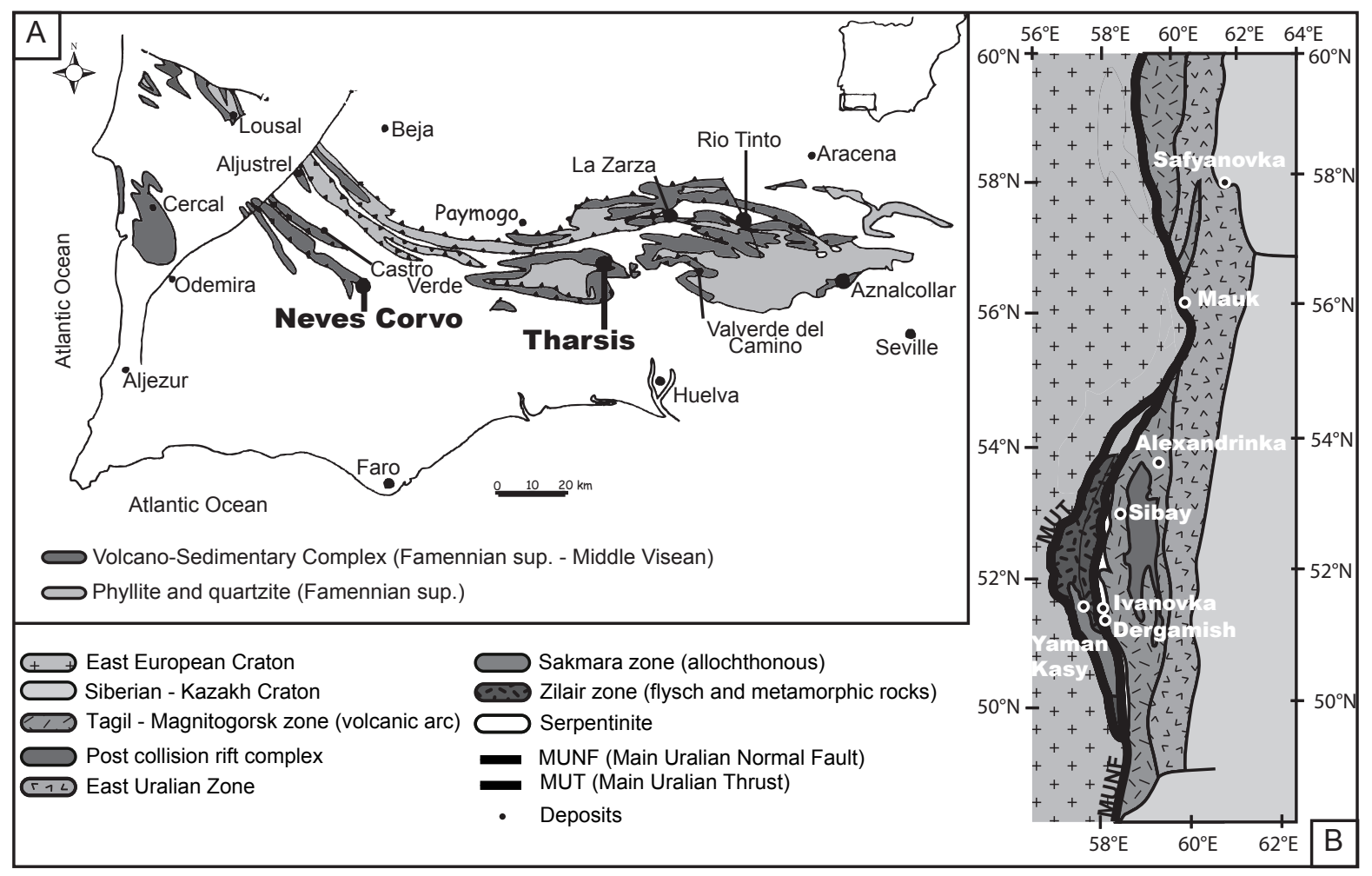

Figure 2 


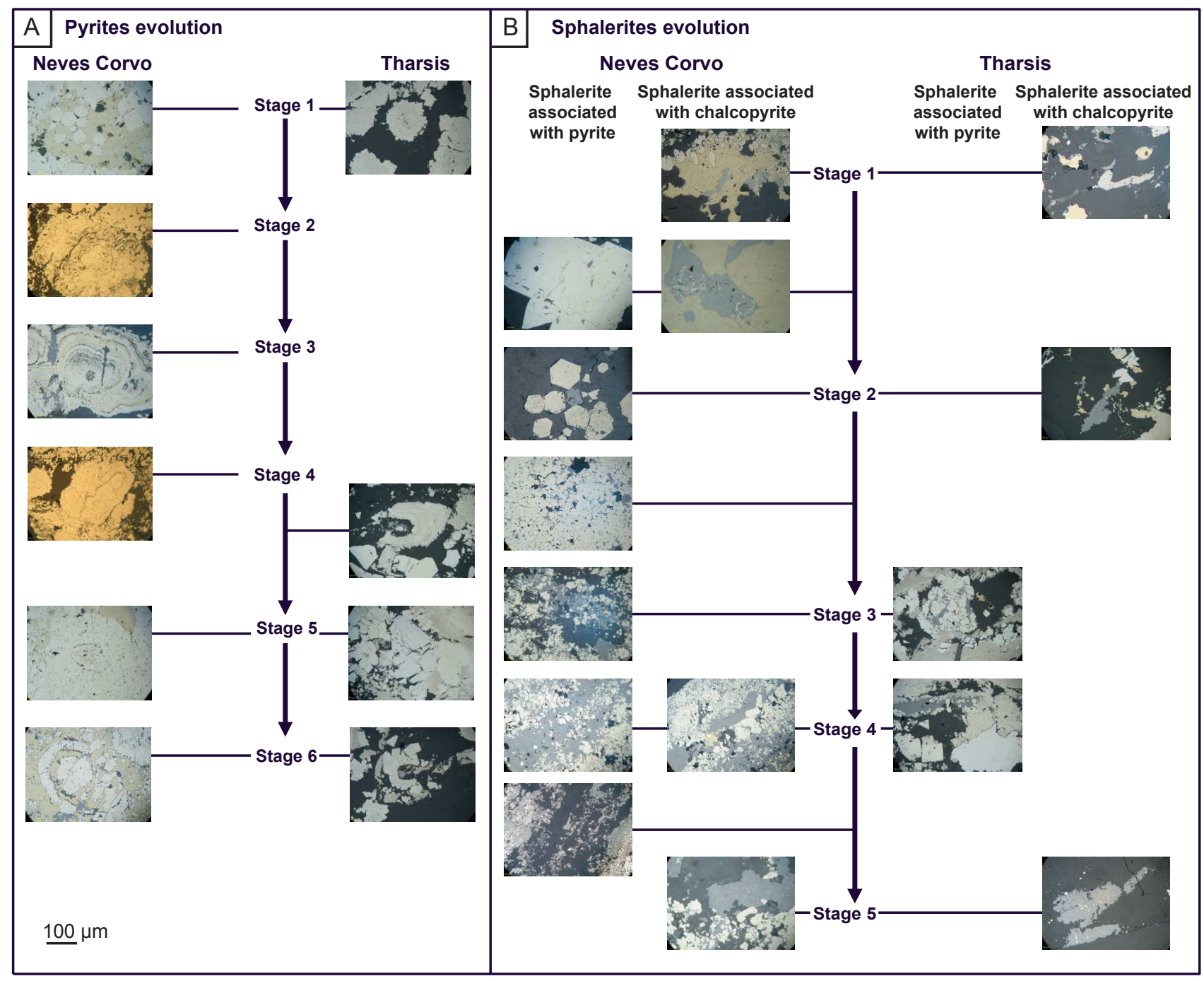

Figure 3 
framboidal pyrites

chalcopyrites

sphalerites

Neves Corvo

Tharsis

Alexandrinka

Sibay

Ivanovka

Dergamish

Yaman Kasy

Mauk

Safyanovka
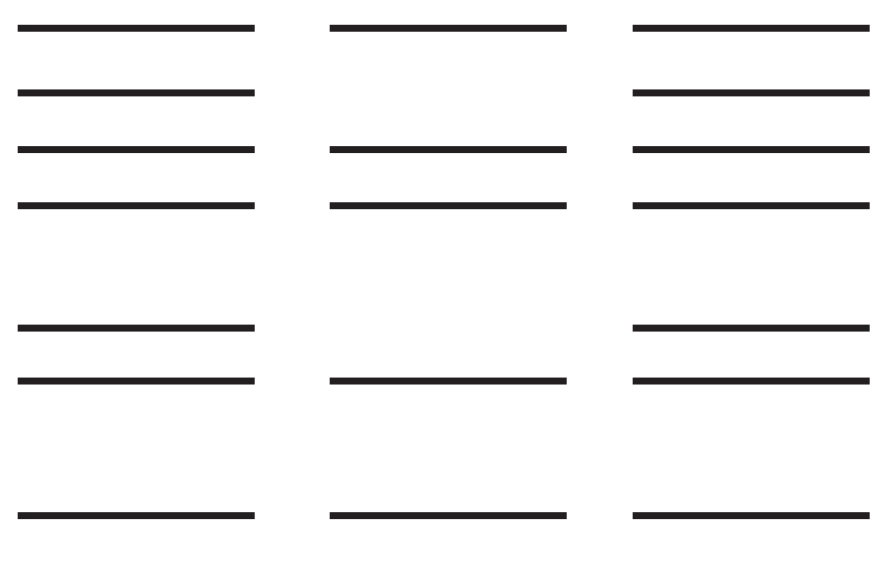

chalcopyrites sphalerites

euhedral pyrites

Fracturing

Time

Figure 4 

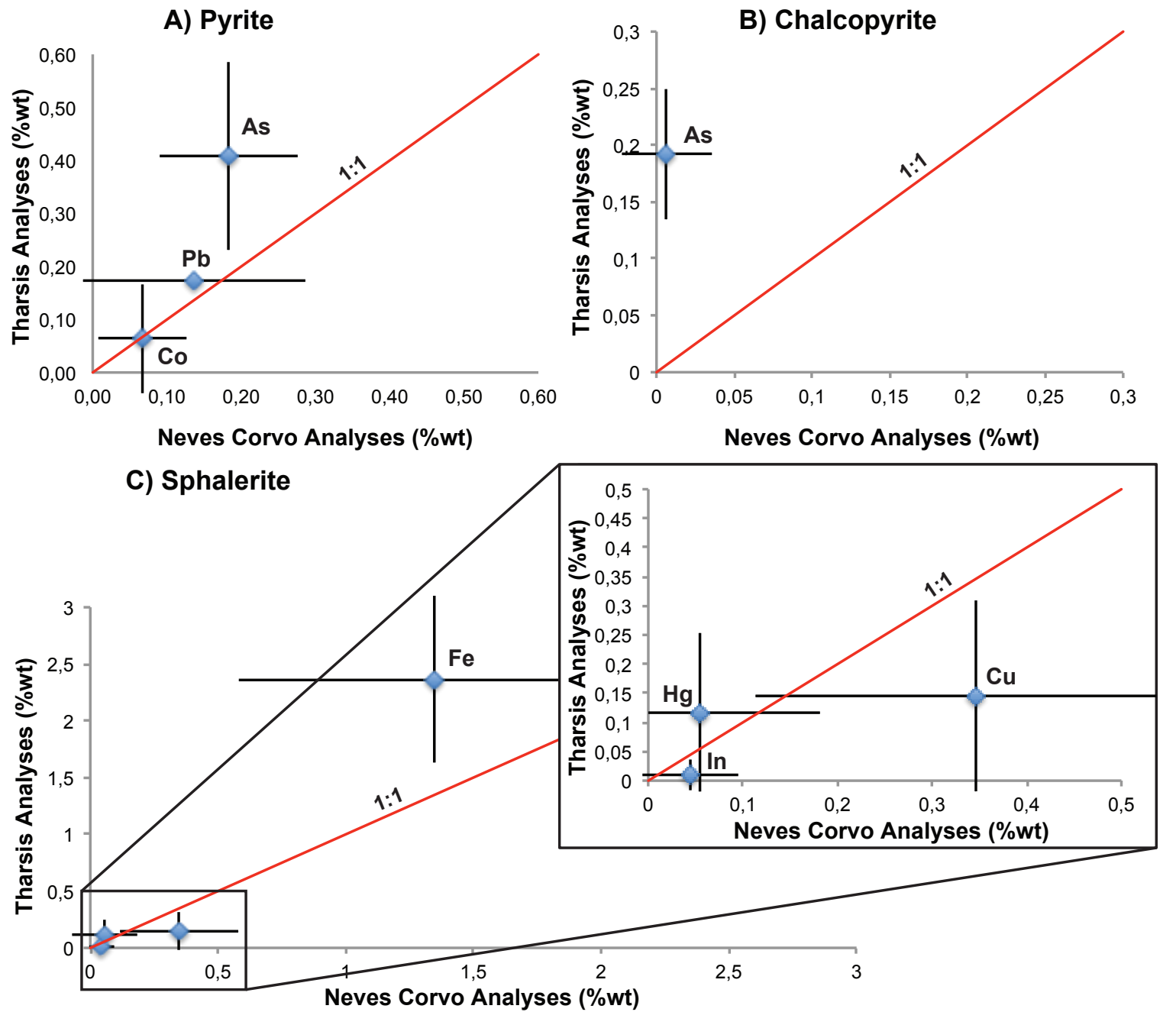

Figure 5 


\begin{tabular}{|c|c|c|}
\hline Deposit & & Neves Corvo \\
\hline \multirow[t]{4}{*}{ Mineralogical composition } & $\mathbf{A A}$ & Pyrite \\
\hline & A & Cassiterite, Sphalerite, Chalcopyrite, Tetrahedrite, Galena \\
\hline & $\mathbf{F}$ & Arsenopyrite, Stannite, Kesterite, Mawsonite \\
\hline & $\mathbf{R}$ & $\begin{array}{l}\text { Pyrrhotite, Bi minerals, Meneghinite, Bournonite, } \\
\text { Co minerals, Cubanite, Enargite, Nekrasovite, Gudmundite, } \\
\text { Stromeyerite, Electrum, Coloradoite, Roquesite, Clausthalite } \\
\text { Naumannite }\end{array}$ \\
\hline \multirow[t]{3}{*}{ Microtextures } & Pyrite & euhedrale, colloform, agglomerate, framboidal \\
\hline & Sphalerite & $\begin{array}{l}\text { euhedral without inclusions, euhedral with growth bands, } \\
\text { in cracks }\end{array}$ \\
\hline & Chalcopyrite & massive, isolated grains or in cracks \\
\hline Pseudo-paragenetic sequence & & $\begin{array}{l}\text { 1) Framboidal pyrites, chalcopyrite and sphalérite } \\
\text { cristallization } \\
\text { 2) Colloform pyrites cristallization } \\
\text { 3) Agglomerates of pyrites cristallization } \\
\text { 4) Euhedral pyrites cristallization } \\
\text { 5) Fracturing } \\
\text { 6) Chalcopyrite and sphalerite cristallization }\end{array}$ \\
\hline \multirow[t]{3}{*}{ Minor elements } & Pyrite & $\mathrm{Pb}, \mathrm{Cu}, \mathrm{As}, \mathrm{Co}, \mathrm{Zn}$ \\
\hline & Sphalerite & In, $\mathrm{Se}, \mathrm{Fe}, \mathrm{Cd}, \mathrm{Cu}, \mathrm{Hg}$ \\
\hline & Chalcopyrite & $\mathrm{Pb}, \mathrm{Ag}, \mathrm{As}, \mathrm{Sn}$ \\
\hline \multirow[t]{3}{*}{ Elements distribution } & Pyrite & $\begin{array}{l}\text { irregular distribution : } \mathrm{As} \\
\text { very irregular distribution }: \mathrm{Pb}, \mathrm{Cu}, \mathrm{Co} \\
\text { extremely irregular distribution }: \mathrm{Zn}\end{array}$ \\
\hline & Sphalerite & $\begin{array}{l}\text { irregular distribution : } \mathrm{Fe}, \mathrm{Cu} \\
\text { very irregular distribution : } \mathrm{In}, \mathrm{Se} \\
\text { ectremely irregular distribution : } \mathrm{Cd}, \mathrm{Hg}\end{array}$ \\
\hline & Chalcopyrite & extremely irregular distribution: $\mathrm{Pb}, \mathrm{Ag}, \mathrm{As}, \mathrm{Sn}$ \\
\hline \multirow[t]{3}{*}{ Experimental memory loss } & $\operatorname{PMexp}(\mathrm{Fe})=$ & $36 \min$ \\
\hline & $\operatorname{PMexp}(\mathrm{Zn})=$ & $3408 \min$ \\
\hline & $\operatorname{PMexp}(\mathrm{Cu})=$ & $14146 \mathrm{~min}$ \\
\hline
\end{tabular}

Figure 6 


\begin{tabular}{|c|c|c|c|}
\hline \multirow[b]{2}{*}{ Deposit } & & \multicolumn{2}{|c|}{ Parameters for discrimination Neves Corvo to Tharsis } \\
\hline & & Neves corvo & Tharsis \\
\hline Mineralogical composition & & $\begin{array}{l}\text { Kesterite, Mawsonite, Bi minerals, Naumannite, } \\
\text { Enargite, Nekrasovite, Gudmundite, Stromeyerite, } \\
\text { Electrum, Coloradoite, Roquesite, Clausthalite }\end{array}$ & $\begin{array}{l}\text { Magnetite, Mackinawite, Bornite, Famatinite, } \\
\text { Bismuthinite, Gold, Tellurobismutite }\end{array}$ \\
\hline \multirow[t]{3}{*}{ Microtextures } & Pyrite & colloform & \\
\hline & Sphalerite & & \\
\hline & Chalcopyrite & & \\
\hline Pseudo-paragenetic sequence & & 2) Colloform pyrites cristallization & \\
\hline \multirow[t]{3}{*}{ Minor elements } & Pyrite & $\mathrm{Cu}, \mathrm{Zn}$ & \\
\hline & Sphalerite & $\mathrm{Se}, \mathrm{Cd}$ & \\
\hline & Chalcopyrite & $\mathrm{Pb}, \mathrm{Ag}, \mathrm{Sn}$ & \\
\hline \multirow[t]{3}{*}{ Elements distribution } & Pyrite & $\begin{array}{l}\text { very irregular distribution : } \mathrm{Pb}, \mathrm{Cu}, \mathrm{Co} \\
\text { extremely irregular distribution : } \mathrm{Zn}\end{array}$ & extremely irregular distribution: Co \\
\hline & Sphal erite & $\begin{array}{l}\text { irregular distribution : } \mathrm{Fe}, \mathrm{Cu} \\
\text { very irregular distribution }: \mathrm{In}, \mathrm{Se} \\
\text { extremely irregular distribution }: \mathrm{Cd}, \mathrm{Hg}\end{array}$ & $\begin{array}{l}\text { regular distribution : } \mathrm{Fe} \\
\text { very irregular distribution : } \mathrm{Cu}, \mathrm{Hg} \\
\text { extremely irregular distribution : In }\end{array}$ \\
\hline & Chalcopyrite & extremely irregular distribution : $\mathrm{Pb}, \mathrm{Ag}, \mathrm{As}, \mathrm{Sn}$ & regular distribution : As \\
\hline \multirow{3}{*}{$\begin{array}{l}\text { Kolmogorov Smirnov test } \\
5 \text { and } 1 \% \text { Quartiles } \\
5 \text { and } 1 \% \text { Deciles }\end{array}$} & Pyrite & \multicolumn{2}{|c|}{ differ: $\mathrm{Co}, \mathrm{As}, \mathrm{Pb}$} \\
\hline & Sphalerite & \multicolumn{2}{|c|}{ differ: $\mathrm{Hg}, \mathrm{Fe}, \mathrm{Cu}, \mathrm{In}$} \\
\hline & Chalcopyrite & \multicolumn{2}{|c|}{ differ: As } \\
\hline \multirow[t]{3}{*}{ Colin White test } & Pyrite & \multicolumn{2}{|c|}{ differ: $\mathrm{As}, \mathrm{Pb} /$ does not differ: $\mathrm{Co}$} \\
\hline & Sphal erite & \multicolumn{2}{|c|}{ differ: $\mathrm{Hg}, \mathrm{Fe}, \mathrm{Cu},(\mathrm{In})$} \\
\hline & Chalcopyrite & \multicolumn{2}{|c|}{ differ: As } \\
\hline
\end{tabular}

Figure 7 


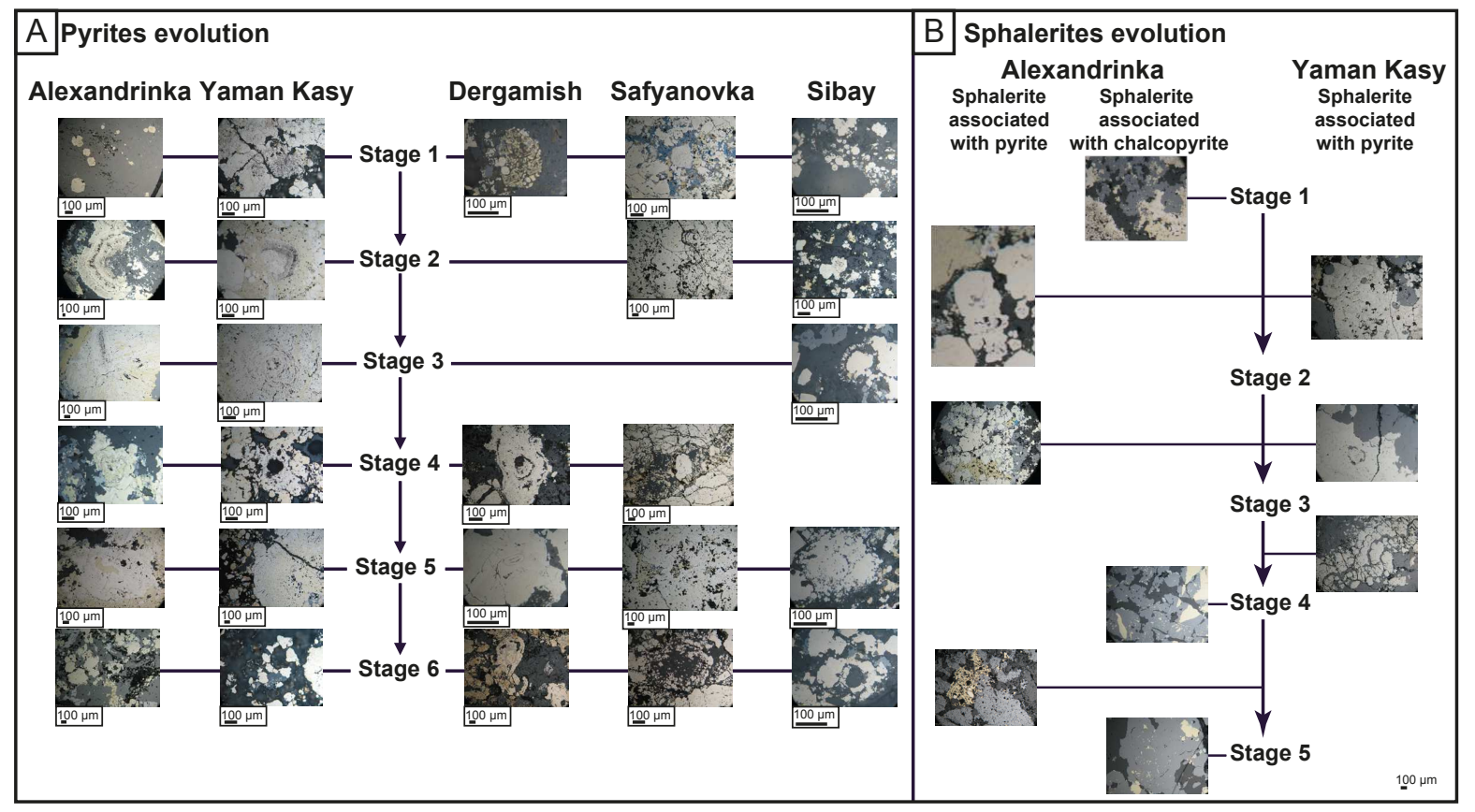

Figure 8 


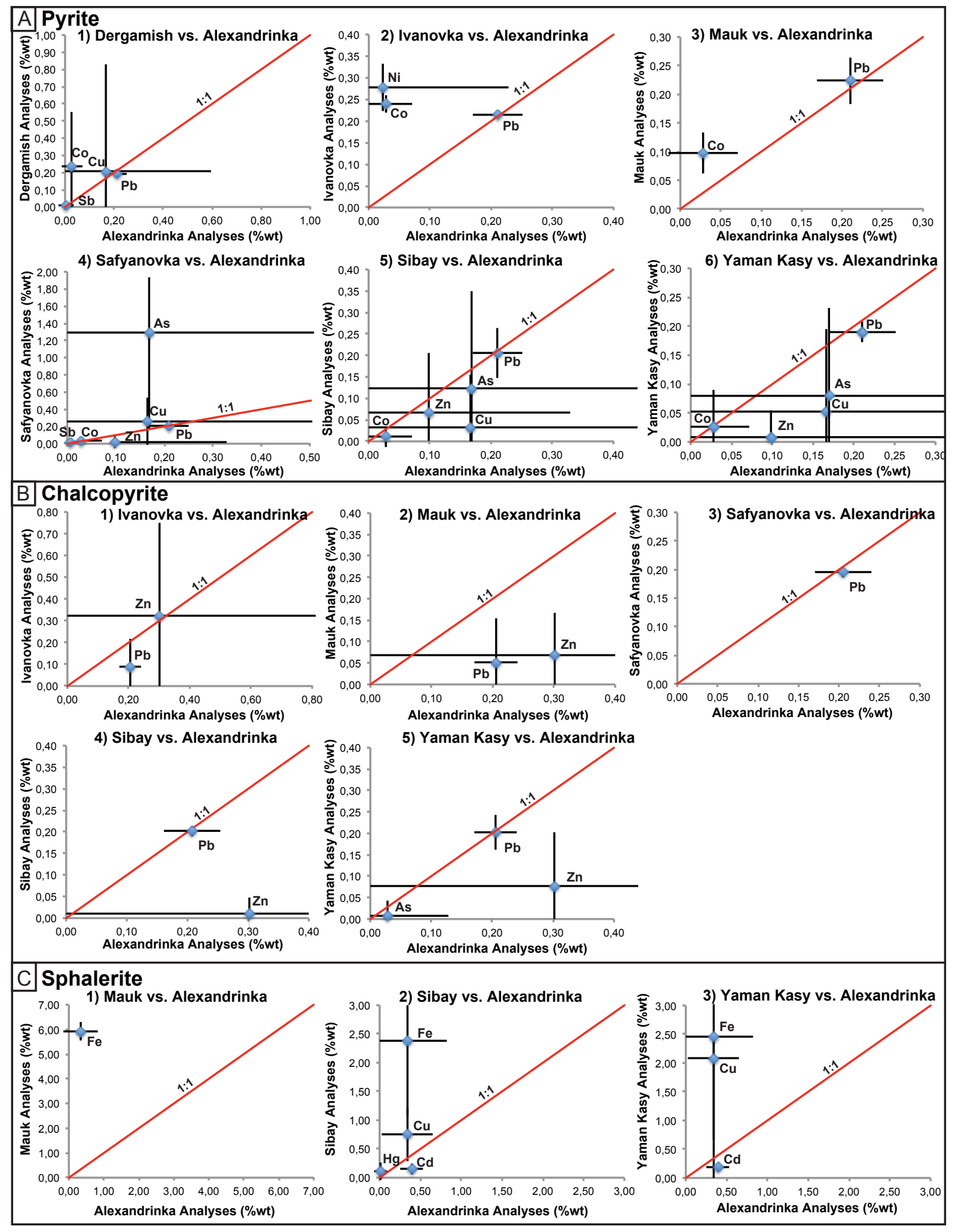

Figure 9 


\begin{tabular}{|c|c|c|c|c|c|c|c|c|}
\hline \multirow[b]{2}{*}{ Deposit } & & \multicolumn{7}{|c|}{$\begin{array}{l}\text { Parameters to discriminate the seven deposits of the Urals province } \\
\end{array}$} \\
\hline & & Alexandrinka & \begin{tabular}{|r|} 
Sibay \\
\end{tabular} & Ivanowa & Dergamish & $\begin{array}{l}\text { Yaman Kasy } \\
\end{array}$ & Mauk & $\begin{array}{r}\text { Safyanovka } \\
\end{array}$ \\
\hline Mineralogical composition & & $\begin{array}{l}\text { Tetraedrite, Zircon, Bomite } \\
\end{array}$ & Magnetite, Siderite & & Marcassite & & Titanite, Apatite & $\begin{array}{l}\text { Covellite, Tennantite } \\
\end{array}$ \\
\hline \multirow{3}{*}{ Microtextures } & Pyrite & & & & & & & \\
\hline & Sphalerite & & & & & & & \\
\hline & Chalcopyrite & & & & & & & \\
\hline \multicolumn{9}{|l|}{\begin{tabular}{|l} 
Pseudo-paragenetic sequence \\
\end{tabular}} \\
\hline \multirow[t]{3}{*}{\begin{tabular}{|l|l|l} 
Minor elements \\
\end{tabular}} & \begin{tabular}{|l} 
Pyrite \\
\end{tabular} & & $\operatorname{In}, \mathrm{Sn}$ & & & $\mathrm{Te}$ & & \\
\hline & Sphalérite & $\mathrm{Sb}$ & & & & & & \\
\hline & Chalcopyrite & & & & & & $\mathrm{Sn}$ & \\
\hline \multirow[t]{3}{*}{ Elements distribution } & $\begin{array}{l}\text { Pyrite } \\
\end{array}$ & extremely irregular distribution $: \mathrm{Ni}$ & $\begin{array}{l}\text { regular distribution : } \mathrm{Pb} \\
\text { extremely irrégular distribution }: \mathrm{In}, \mathrm{Sn}\end{array}$ & very regular distribution : $\mathrm{Co}, \mathrm{Ni}$ & & extremely irregular distribution $: \mathrm{Te}$ & regular distribution: Co & very irregular distribution : $\mathrm{As}, \mathrm{Cu}$ \\
\hline & Sphalerite & $\begin{array}{l}\text { very irregular distribution }: \mathrm{Fe} \\
\text { extremely irregular distribution }: \mathrm{Sb}, \mathrm{Hg}\end{array}$ & $\begin{array}{l}\text { irregular distribution }: \mathrm{Cu}, \mathrm{Cd} \\
\text { very irregular distribution }: \mathrm{Hg}\end{array}$ & & & extremely irregular distribution $: M n$ & very regular distribution: $\mathrm{Fe}$ & \\
\hline & Chalcopyrite & & & very irregular distribution : $\mathrm{Pb}$ & & & extremely irregular distribution $: \mathrm{Pb}, \mathrm{Sn}$ & \\
\hline \multirow{3}{*}{$\begin{array}{l}\text { Kolmogorov Smirnov test } \\
5 \text { and 1\% Quartiles } \\
5 \text { and 1\% Deciles } \\
\end{array}$} & Pyrite & \multicolumn{7}{|c|}{ differ: $\mathrm{Co}, \mathrm{Pb},(\mathrm{Cu})$} \\
\hline & Sphalerite & \multirow{2}{*}{\multicolumn{7}{|c|}{$\begin{array}{c}\text { differ: } \mathrm{Fe}, \mathrm{Cu}, \mathrm{Cd} \\
\text { differ: } \mathrm{Pb}, \mathrm{Zn} \\
\end{array}$}} \\
\hline & Chalcopyrite & & & & & & & \\
\hline \multirow[t]{2}{*}{ Colin White test } & Pyrite & \multicolumn{7}{|c|}{$\frac{\text { differ: } \mathrm{Pb},(\mathrm{Co})}{\mathrm{differ} \cdot \mathrm{Cd} / \mathrm{does} \text { not differ }}$} \\
\hline & \begin{tabular}{|l|l|} 
Sphalerite \\
Chalcoprite
\end{tabular} & \multicolumn{7}{|c|}{$\begin{array}{l}\text { differ: } \mathrm{Cd} / \mathrm{does} \text { not diffe } \\
\mathrm{differ}: \mathrm{Pb},(\mathrm{Zn})\end{array}$} \\
\hline
\end{tabular}

Figure 10 

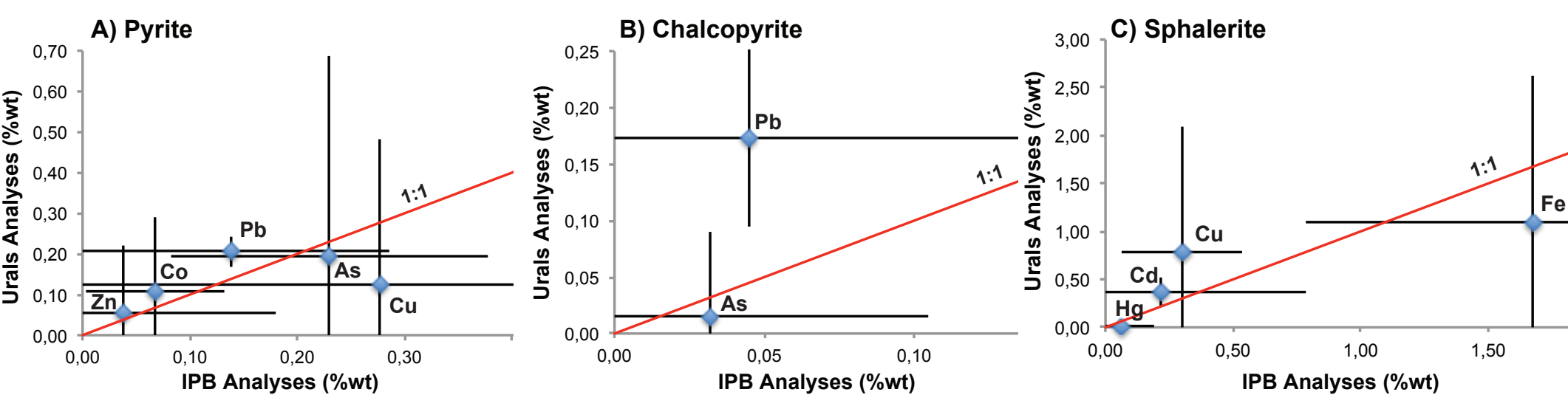

Figure 11 


\begin{tabular}{|c|c|c|c|}
\hline \multirow[b]{2}{*}{ Deposit } & & \multicolumn{2}{|c|}{ Parameters discriminating the South-Iberian province to the Urals province } \\
\hline & & IPB & Urals \\
\hline Mineralogical composition & & $\begin{array}{l}\text { Cassiterite, Arsenopyrite, Stannite, Kesterite, Mawsonite, Bi minerals, } \\
\text { Meneghenite, Bournonite, Famatinite, Co minerals, Cubanite, Enargite, } \\
\text { Nekrasovite, Gudmundite, Stromeyerite, Electrum, Coloradoite, Roquesite, } \\
\text { Clausthalite, Naumannite, Mackinawite, Cobaltite, Bismuthinite, Gold, } \\
\text { Tellurobismutite }\end{array}$ & $\begin{array}{l}\text { Covellite, Ilmenite, Zircon, Baryte, Iron oxyde, Titanite, Apatite, Tennantite, } \\
\text { Siderite, Marcassite. }\end{array}$ \\
\hline \multirow{3}{*}{ Microtextures } & Pyrite & & \\
\hline & Sphalerite & & \\
\hline & Chalcopyrite & & \\
\hline \multicolumn{4}{|l|}{ Pseudo-paragenetic sequence } \\
\hline \multirow{3}{*}{ Minor elements } & Pyrite & & $\mathrm{Ni}$ \\
\hline & Sphalerite & Se, In & $\mathrm{Sb}$ \\
\hline & Chalcopyrite & $\mathrm{Ag}, \mathrm{Sn}$ & $\mathrm{Zn}$ \\
\hline \multirow[t]{3}{*}{ Element distribution } & Pyrite & $\begin{array}{l}\text { irregular distribution : } \mathrm{As} \\
\text { very irregular distribution : } \mathrm{Cu}, \mathrm{Co}, \mathrm{Pb}\end{array}$ & $\begin{array}{l}\text { regular distribution }: \mathrm{Pb} \\
\text { extremely irregular distribution : } \mathrm{Cu}, \mathrm{As}, \mathrm{Co}, \mathrm{Ni}\end{array}$ \\
\hline & Sphalerite & $\begin{array}{l}\text { irregular distribution : } \mathrm{Fe}, \mathrm{Cu} \\
\text { very irregular distribution : } \mathrm{In} \\
\text { extremely irregular distribution : } \mathrm{Se}, \mathrm{Cd}\end{array}$ & $\begin{array}{l}\text { irregular distribution : } \mathrm{Cd} \\
\text { extremely irregular distribution : } \mathrm{Cu}, \mathrm{Sb}, \mathrm{Fe}\end{array}$ \\
\hline & Chalcopyrite & extremely irregular distribution : Ag & extremely irregular distribution : $\mathrm{Zn}$ \\
\hline \multirow{3}{*}{$\begin{array}{l}\text { Kolmogorov-Smirnov test } \\
5 \text { et } 1 \% \text { Quartiles } \\
5 \text { et } 1 \% \text { Deciles } \\
\end{array}$} & Pyrite & \multicolumn{2}{|c|}{ differ: $\mathrm{Pb}, \mathrm{As}, \mathrm{Cu}, \mathrm{Zn}, \mathrm{Co}$} \\
\hline & Sphalerite & \multicolumn{2}{|c|}{ differ: $\mathrm{Fe}, \mathrm{Hg}, \mathrm{Cu}, \mathrm{Cd}$} \\
\hline & Chalcopyrite & \multicolumn{2}{|c|}{ differ: $\mathrm{Pb}, \mathrm{As}$} \\
\hline \multirow[t]{3}{*}{ Colin-White test } & Pyrite & \multicolumn{2}{|c|}{ differ: $\mathrm{Pb}, \mathrm{As}, \mathrm{Cu}, \mathrm{Zn}, \mathrm{Co}$} \\
\hline & Sphalerite & \multicolumn{2}{|c|}{ differ: $\mathrm{Fe}, \mathrm{Hg}, \mathrm{Cu}, \mathrm{Cd}$} \\
\hline & Chalcopyrite & \multicolumn{2}{|c|}{ differ: $\mathrm{Pb}, \mathrm{As}$} \\
\hline
\end{tabular}

Figure 12 


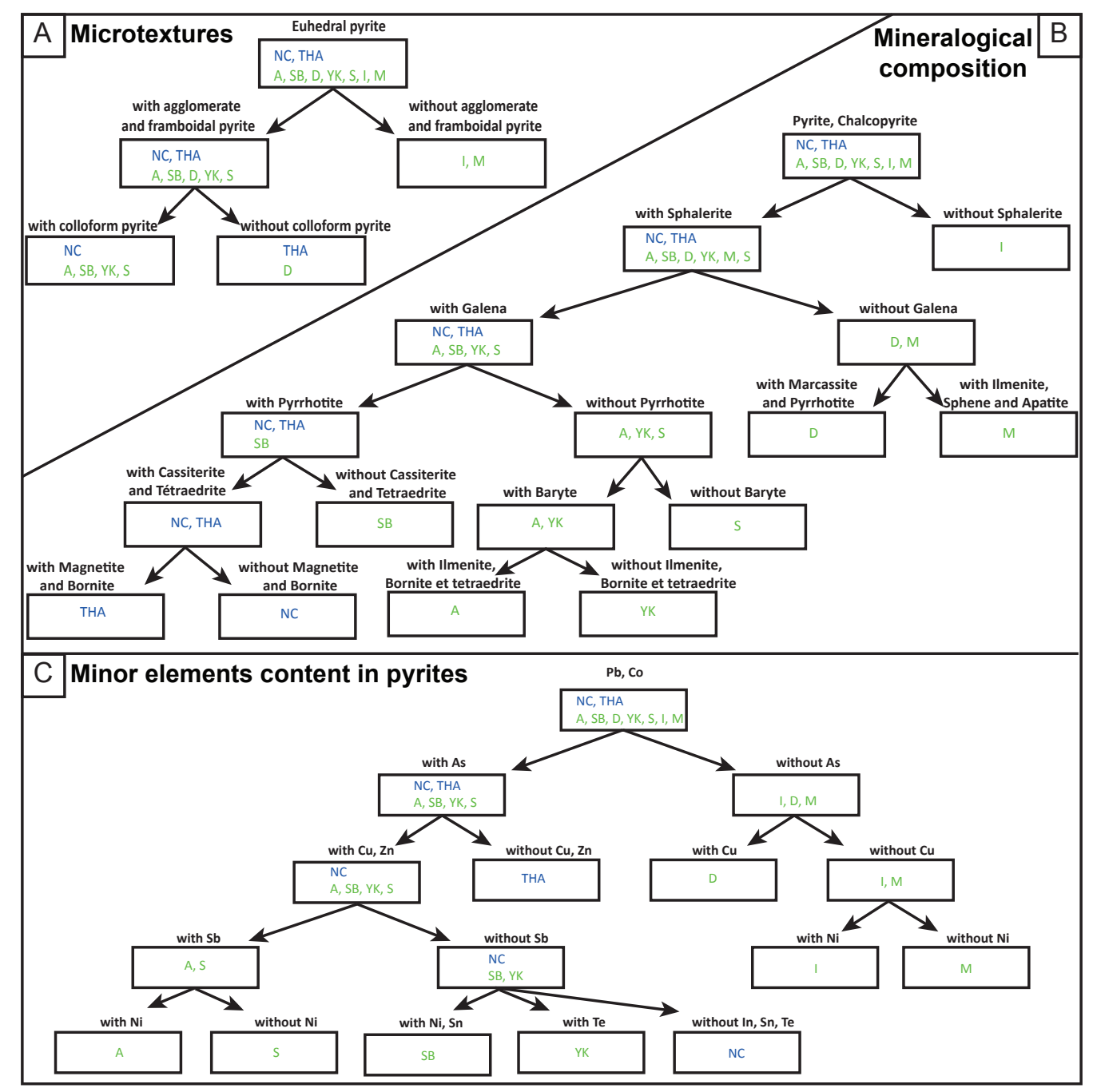

Figure 13 